\title{
Kernos
}

Revue internationale et pluridisciplinaire de religion grecque antique

$23 \mid 2010$

Varia

\section{Locating Sanctuaries in Upper Macedonia According to Archaeological Data}

\section{Kalliopi Chatzinikolaou}

\section{(2) OpenEdition \\ Journals}

\section{Édition électronique}

URL : http://journals.openedition.org/kernos/1580

DOI : 10.4000/kernos. 1580

ISSN : 2034-7871

\section{Éditeur}

Centre international d'étude de la religion grecque antique

\section{Édition imprimée}

Date de publication : 1 janvier 2010

Pagination : 193-222

ISSN : 0776-3824

\section{Référence électronique}

Kalliopi Chatzinikolaou, « Locating Sanctuaries in Upper Macedonia According to Archaeological Data », Kernos [En ligne], 23 | 2010, mis en ligne le 10 octobre 2013, consulté le 30 avril 2019. URL http://journals.openedition.org/kernos/1580; DOI : 10.4000/kernos.1580 


\title{
Locating Sanctuaries in Upper Macedonia According to Archaeological Data
}

\begin{abstract}
The region of Upper Macedonia (Macedonia's north-western extremity, which was frequently referred to in ancient sources) became a field of controversy, fusions and syncretism over the course of its history due to its distinct geographical location and the diversity of its population. The region consisted of a mainly rural population despite having some urban centres. This population maintained its tribal and cultural characteristics until Late Antiquity. The four member areas Elimeia, Eordaia, Orestis and Lyncestis formed a conservative yet active core, annexing or de-annexing regions in accordance with historical developments shaped by ambitious rulers desirous of expanding their dominion. Apart from sites where sanctuaries would be expected, for example, in urban centres or the sites of identified settlements, such as Aiane, Heraclea Lyncestis, Petres and Eratyra, the other attested sanctuaries of Upper Macedonia are located: a) on the crests of hills or on mountaintops (sanctuaries of Zeus Hypsistos); b) at hubs, probably as the result of a cult's wide influence (sanctuaries of Apollo), and c) in passages, because of a cult's dissemination (sanctuaries of Enodia). Thus, sanctuary locations follow the general geographical distribution of cities and settlements. According to the present excavation data, these sanctuaries do not display monumentality, which is a characteristic of the Macedonian region.
\end{abstract}

Résumé : La région de la Haute Macédoine (Élimée, Éordée, Orestide et Lyncestide), la zone extrême de la Macédoine du Nord, souvent évoquée par les sources anciennes, en raison de sa position géographique particulière et de ses populations d'origines différentes, a constitué un terrain d'affrontements, de fusions et de manifestations de syncrétisme des courants et croyances religieux au cours de sa marche dans le temps. Il s'agit d'une région à population surtout rurale, malgré la présence de certains centres urbains, laquelle a conservé ses traits de culture jusqu'à l'antiquité tardive. Les quatre régions particulières d'Élimée, d'Éordée, d'Orestide et de Lyncestide constituent un noyau actif bien que conservateur, où se rattachent et dont se détachent des régions au cours de l'histoire, un phénomène notamment déterminé par les aspirations conquérantes des souverains. Au-delà des sites attendus des sanctuaires dans les villes ou zones d'agglomérations identifiées, comme Aiané, Héraclée Lyncestice, Pétrès, Ératyra, les autres sanctuaires attestés de la Haute Macédoine sont situés au sommet de collines ou de montagnes (sanctuaires de Zeus Hypsistos), à des points de passages importants, ce qui est probablement dû à la grande portée du culte (sanctuaires d'Apollon), ou à de simples passages, en fonction de la propagation du culte, (sanctuaires d'Énodia). Leur situation suit donc la répartition géographique générale des villes et agglomérations à quelques légères différences près. Selon les données archéologiques connues jusqu'ici, ces sanctuaires ne présentent pas de constructions monumentales, ce qui est l'une des caractéristiques de l'espace macédonien. 


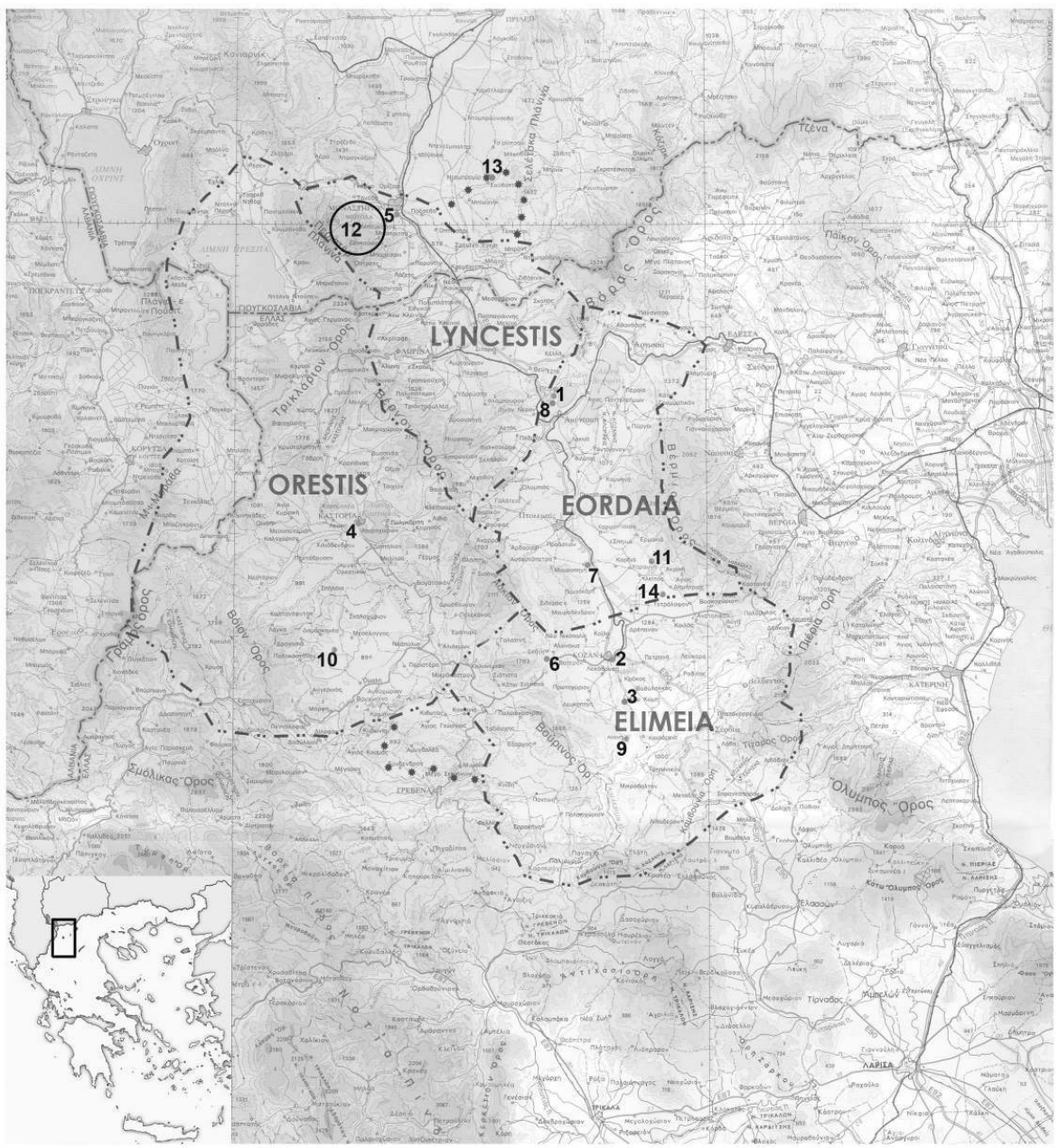

\section{Map 1: Upper Macedonia}

$$
\begin{array}{cl}
-\cdots+\cdots & \text { Boundaries of ancient regions } \\
* & \begin{array}{l}
\text { Expanded boundaries } \\
\text { of ancient regions } \\
\text { Sanctuary sites }
\end{array}
\end{array}
$$

Scale : $1: 1,000,000$
1.Sanctuary of Zeus

2.Sanctuary site

3.Sanctuary of Dionysus

4.Sanctuary of Zeus Hypsistos

5.Sanctuary of Zeus Hypsistos

6.Sanctuary of Apollo

7.Sanctuary of Apollo

8.Sanctuary site - Sanctuary of Athena ?

9.Sanctuary of Pluto

10.Sanctuary of Hecate

11.Sanctuary of Enodia

12.Sanctuary of Artemis Ephesia

13.Sanctuary of Passikrata

14.Sanctuary of Herakles 


\section{Upper Macedonia. The region}

Herodotus first refers to the name of the region of Upper Macedonia (Map 1) in describing Xerxes' invasion of Thessaly and the wanderings of Perdiccas, founder of the Kingdom of Aigae. ${ }^{1}$ The sources $^{2}$ and previous research do not clearly define the geographical boundaries of this area. There is relative consensus only on Elimeia, Orestis, Lyncestis, and Pelagonia, while Eordaia initially belonged administratively to Lower Macedonia, despite the fact that geographically it belonged to Upper Macedonia. Recent research ${ }^{3}$ has added Dassaretis, Derriopos, Tymphaea, and Atintania to the above-mentioned regions, primarily in referring to the Roman province of Macedonia.

Upper Macedonia, secluded and mountainous, occupied a distinct geographical location, which to some extent justifies its population diversity. For these reasons it became a field of cultural controversy, fusions, and syncretism over the course of its history. The four constituent areas of Elimeia, Eordaia, Orestis, and Lyncestis formed a conservative yet active core, annexing or deannexing regions in accordance with historical developments shaped by ambitious rulers desirous of expanding their dominion. Upper Macedonia was a region with a largely rural population despite some urban centres. This population maintained its tribal and cultural characteristics until Late Antiquity. ${ }^{4}$

\section{Zeus}

A considerable body of evidence and material remains from the Hellenistic and above all, Roman periods have been found in situ or dispersed and linked with the cults of at least thirty different deities and heroes and correspondingly, in most cases, with their sanctuaries. ${ }^{5}$ A significant percentage of this evidence relates to the cult of Zeus.

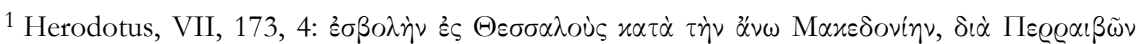

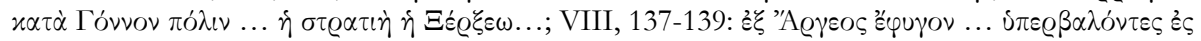
$\tau \dot{\eta} \nu \alpha \ddot{\alpha} \omega \omega \mathrm{M} \alpha x \varepsilon \delta o v i \eta \eta$

2 Thucydides, II, 99, 1-2, explicitly mentions the division of Upper and Lower Macedonia; Strabo, VII (C326), mentions the geographical boundaries of four member parts of Upper Macedonia. Livius, XLV, 29, 9, mentions the division of Macedonia into four parts (merides) and defines Upper Macedonia as the Fourth Meris, with Pelagonia as its seat.

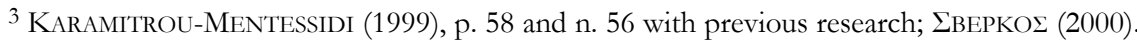
They accept the extended boundaries.

${ }^{4}$ On the discussion of the geographical boundaries of the area: K.G. CHATZINIKOLAOU,

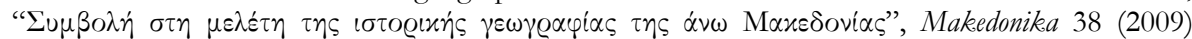
(forthcoming).

${ }^{5}$ Here, we examine somewhat sparingly all data bringing together maximum possibilities for identifying sanctuary sites by combining excavation results or visible antiquities and finds found in situ through previous research. 
A sanctuary ${ }^{6}$ (Map 1, nr. 1) and epigraphically ${ }^{7}$ attested cult of Zeus were found at the Hellenistic settlement of Petres in Eordaia (Fig. 1a-b). The sanctuary, discovered south of the so-called Synoikia tis Krinis (Fountain Quarter) and consisting of three spaces and a square monumental altar, was probably situated in the sector of public sanctuaries. This sanctuary seems to have been one of the ancient city's most important, and is connected with a complex of structures that included workshops, mills, and storage spaces.

The first excavation results from this site have been presented from time to time, but the sanctuary and its portable finds remain largely unpublished.

\section{Zeus Hypsistos at Elimeia}

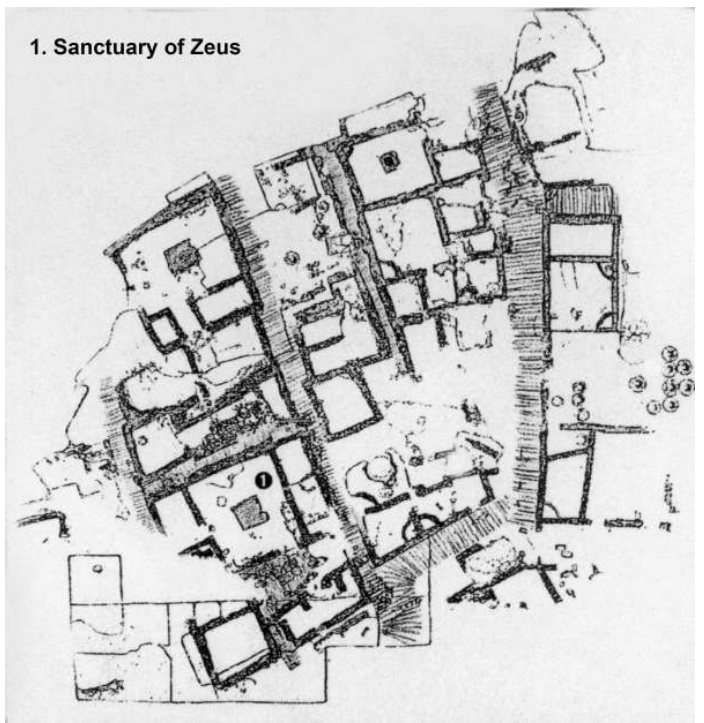

Fig. 1a-b

A large number of marble votive reliefs to Zeus Hypsistos of the Roman period come from various sites in Upper Macedonia, showing how widespread this god's cult was, probably after the Roman conquest ${ }^{8}$. Some of the sites that provide the most evidence and therefore the greatest possibilities for the

6 ADAM-VELENI (1988), p. 9, pl. 2, 2; ADAM-VELENI (1997), p. 10-11, fig. 10; ADAM-VELENI (1998a), p. 20-22, fig. 1-4; ADAM-VELENI (1998b), p. 46 plan 5, p. 47-48 fig. 29, p. 50, 53, 57;

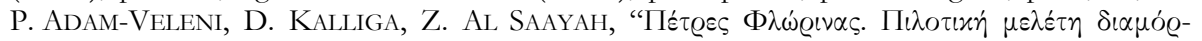

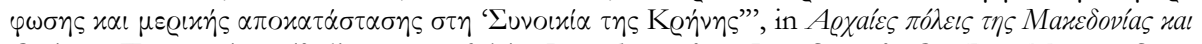

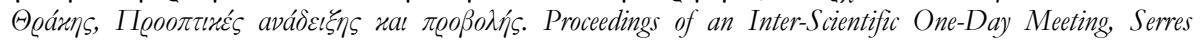
11.12.1999, Thessaloniki, 2008, p. 87-110. Cf. CHATZINIKOLAOU (2007), Catalogue, nr. 2.

7 Adam-Veleni (1997), p. 10-11; AdAm-Veleni (1998a), p. 21; AdAm-Veleni (1998b), p. 50 fig. 30, p. 53 (simple mentions). Cf. Chatzinikolaou (2007), Catalogue, nr. 3. The altar of Zeus and the name of the god without a cult epithet are mentioned in the inscription that identified the site. The evidence to date cannot define the identity of the deity, and the possibility of some local cult cannot be excluded. This was a case of a Zeus cult practiced from the Hellenistic period onward in Upper Macedonia, and was probably of a general nature.

${ }^{8}$ CHATZINIKOLAOU (2008) (forthcoming). 
presence of sanctuaries include the hill of Hagios Eleutherios in Kozani located at Elimeia, ascertained to have been inhabited from the Prehistoric to the Roman period (Map 1, nr. 2), ${ }^{9}$ (Fig. 210, 311), Ano Komi12 (Fig. 4-5), and Aiane and its wider region ${ }^{13}$ (Fig. 6-8). Most of these sites have not been systematically excavated. However, the portable finds indicate the existence of sanctuaries which do not necessarily correlate with each other, at least as regards their origin. They include late Hellenistic and Roman votive reliefs and stelae, often inscribed with depictions of eagles and Zeus Hypsistos in the iconographical type of Zeus wearing a himation and holding a sceptre, usually accompanied by an eagle or offering a libation at an altar. ${ }^{14}$ Similar examples are reported from Pydna and Dion in Pieria, ${ }^{15}$ Edessa, ${ }^{16}$ Beroia $^{17}$ and Kyrros $^{18}$ in Bottiaea, Giannitsa and Agrosykia at Pella, and sites in Paionia. ${ }^{19}$

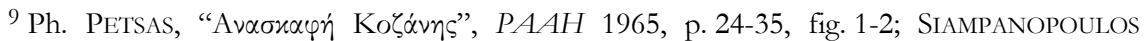
(1974), p. 36-37, 50-51, fig. 8; KARAMITROU-MENTESSIDi (1993a), p. 32, Chrysostomou (1994), p. 101, Chrysostomou (1996), p. 27, 47; Karamitrou-Mentessidi (1997), p. 221-222. Cf. Chatzinikolaou (2007), Catalogue, nr. 6.

10 A) The Archaeological Collection of Kozani, Inv. nr. 181 : RizAKIS, TouratsogLOU (1985), p. 21 nr. 3, pl. 2 with previous bibliography; CHRYSOSTOMOU (1996), p. 46 nr. 1. Cf. Chrysostomou (1994), p. 101 nr. 1, fig. 10x; Chatzinikolaou (2007), Catalogue, nr. 7: a

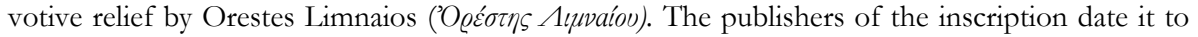
the 2 nd century BC, keeping the dating previously proposed by $\mathrm{Ph}$. Petsas. This is among the very early evidence for the god's cult. However, evidence that would date the monument before the middle of the century is insufficient. See CHATzinikolaOU (2008) (forthcoming). B) The Archaeological Collection of Kozani, Inv. nr. 179: RIZAKIS, TOURATSOGLOU (1985), p. 22-23 nr. 5, pl. 2 with previous bibliography; Chrysostomou (1996), p. 27. Cf. KARAMitrouMentessidi (1993a), p. 78, 80-81 fig. 94; Chrysostomou (1994), p. 101, fig. $10 \delta$ (simple mentions); ChatzinikolaOU (2007), Catalogue, nr. 8: later than the above-mentioned relief, it might be dated to the $1^{\text {st }}$ century BC. The epithet Kronides (Køovi $\delta \eta \varsigma$ ), which is attributed to Zeus, is not known from other epigraphic texts in Macedonia. This epithet is simply used to mention the name of Kronos, Zeus' father, and is widely used in ancient Greek literature, though not in invocations (epiclesis).

11 Rizakis, Touratsoglou (1985), p. 36-37 nr. 21, pl. 6 with previous bibliography; Chrysostomou (1996), p. 46 nr. 2. Cf. Chrysostomou (1994), p. 101 nr. 2, fig. 10ı; ChatziniKOLAOU (2007), Catalogue, nr. 9.

12 Rizakis, Touratsoglou (1985), p. 26-27 nr. 10, pl. 4, p. 33-34 nr. 16-17, pl. 6-7 with previous bibliography; CHRYsostomou (1996), p. 46 nr. 2, p. $48-49$ nr. 1-3, 5, p. 52-53 nr. 1 [Prefecture of Kozani], pl. 11ß. Cf. Chrysostomou (1994), p. 102-103, fig. 10-11; ChatzinikoLAOU (2007), Catalogue, nr. 13-20.

13 Rizakis, Touratsoglou (1985), p. 24 nr. 7, pl. 3, p. 43 nr. 27, pl. 9 with previous bibliography; CHrysostomou (1996), p. 47 nr. 1, p. 54 (ascribing it to Tymphaea), p. 47-49 nr. 2 3, 5-7, pl. 11. Cf. Chrysostomou (1994), p. 101-103, fig. 11; KARAmitrou-Mentessidi (1999), p. 196 and n. 596; Chatzinikolaou (2007), Catalogue, nr. 11, 12, 25 - 30.

${ }^{14}$ Libation is the only act in the cult ritual which the gods are depicted performing in ancient Greek art. See E. SIMON, Opfernde Götter, Berlin, 1953 (note that the title may incorrectly imply offerings in general and not only libations). Cf. the notes of VOUTIRAS (1990), 124 and accompanying $\mathrm{n} .3$ with the relevant bibliography.

15 Chrysostomou (1996), p. 44-45, pl. 10 (Pydna). D. Pandermalis, "Zeús úqı ' $\lambda \lambda \alpha^{\prime \prime}$, AEMTh 17 (2003) [2005], p. 418-424. 

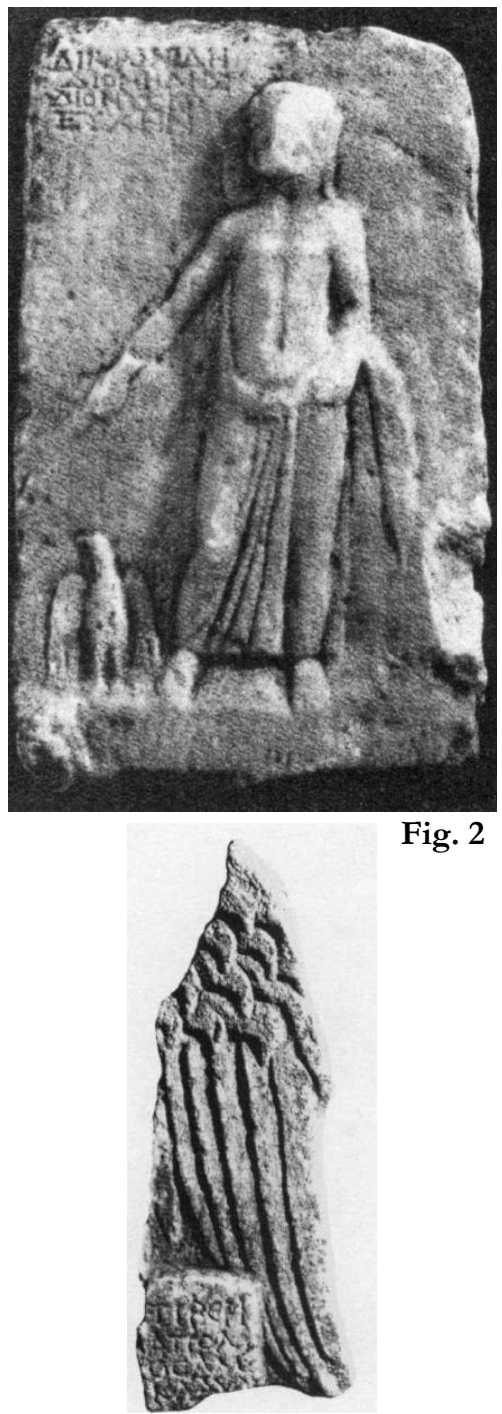

Fig. 5

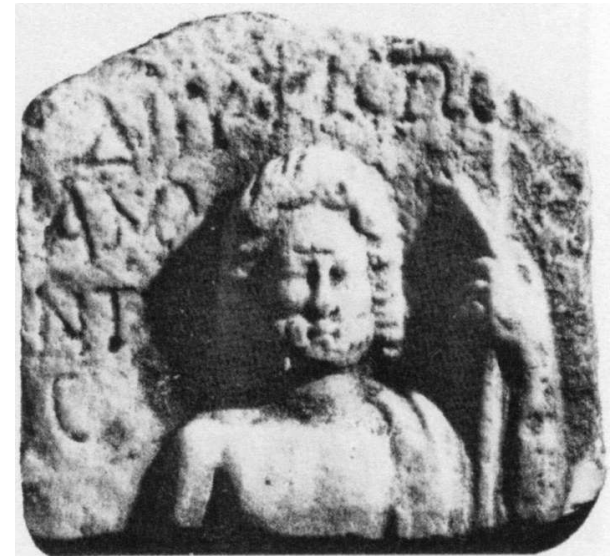

Fig. 3

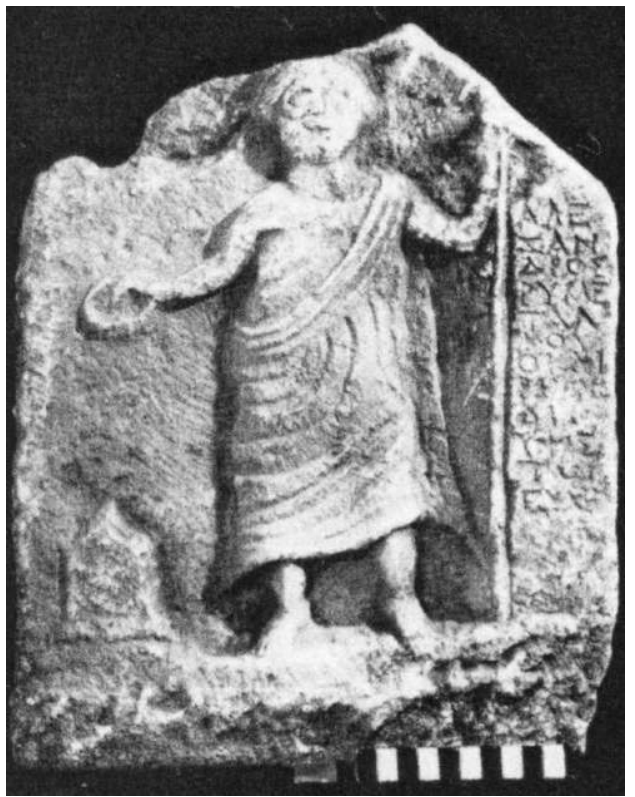

Fig. 4

Specifically, the site of "Profetes Elias" at Ano Komi is a hillock dedicated to the Prophet Elias and, as elsewhere in Greece, it may indicate an earlier pagan cult ${ }^{20}$ connected with a ritual that took place at a specific period, since it

\footnotetext{
${ }^{16}$ Chrysostomou, l.c. (n. 15), p. 30-32, pl. 7 (Edessa), p. 34-35, pl. $8 \alpha$ (Petria).

17 Ibid., p. 35-40, pl. 8.

18 Ibid., p. 40-41, pl. 9.

${ }^{19}$ Ibid., p. 42-43, pl. 9 (Giannitsa, Agrosykia), p. 56 (Paionia).

${ }^{20}$ Similar toponyms that refer to a previous cult are located at various sites in Greece: VOUTIRAS (2006), p. 341 and n. 74 with previous bibliography.
} 
lies in a mountainous region not always easily accessible. Since these sites were close to each other and near the city of Aiane, the capital of Elimeia, it is very likely there are one or two sanctuaries of Zeus Hypsistos, which drew votive offerings from Elimeians from the late Hellenistic to the late Roman period.

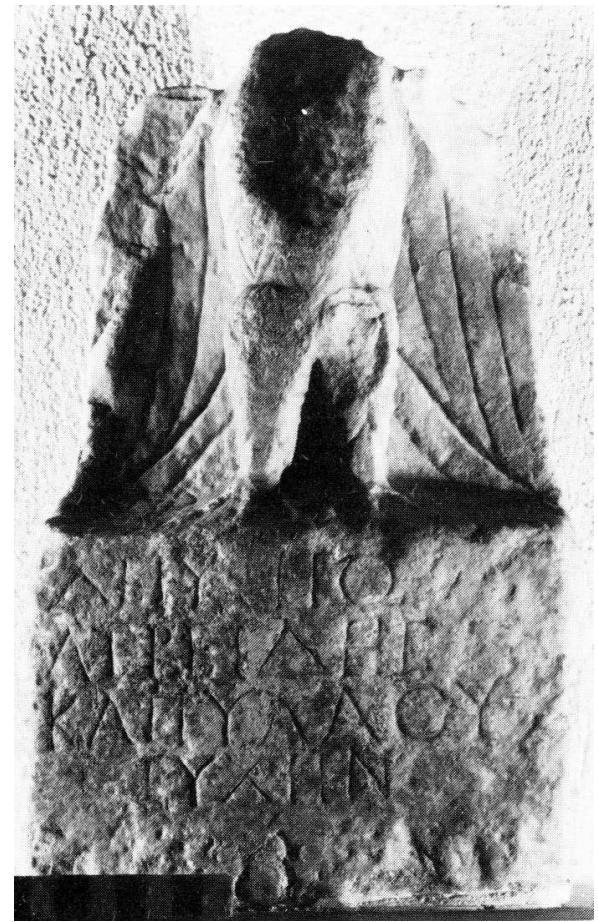

Fig. 6
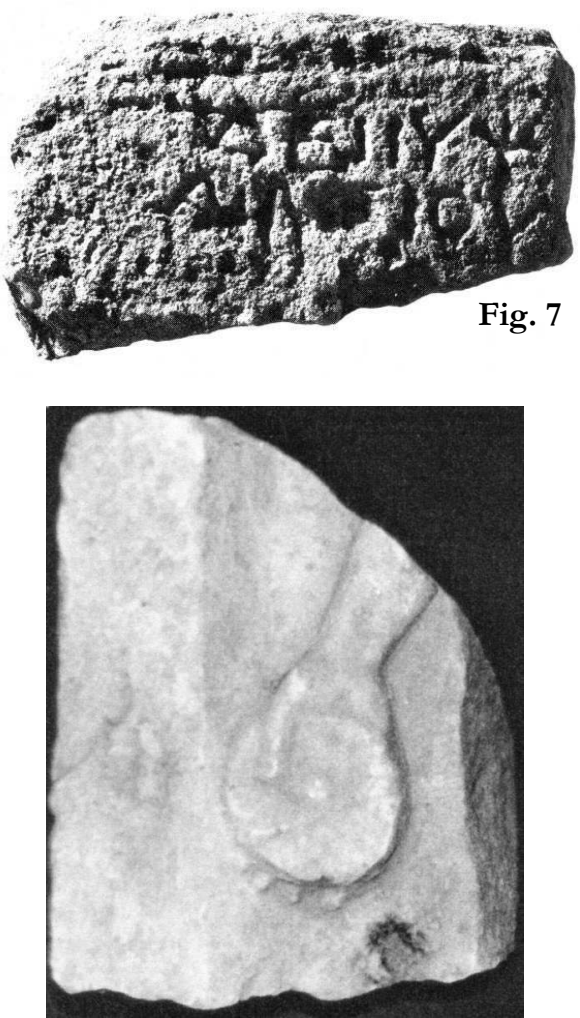

Fig. 8

\section{Dionysus}

Epigraphic evidence for the cult of Dionysus was found at the site of Ano Komi, and included three votive monuments, two of them architectural members. An inscribed section of a pedestal facade from the site of "Profetes Elias" (Fig. 9) ${ }^{21}$ refers to a statue erected in honour of Dionysus. A column drum with a votive inscription to Dionysus from the Roman period was found

${ }^{21}$ Rizakis, Touratsoglou (1985), p. 27-28 nr. 11, pl. 4 with previous bibliography. $C f$. Chatzinikolaou (2007), Catalogue, nr. 134. The slab was found in the ruins of the Christian church of Prophetes Elias and was later used as a threshold. It was later built into the narthex of the church of Saint Georgios, where it was found by Th. Rizakis and I. Touratsoglou, the inscription's publishers. Today, the slab is missing. 
at this site in $1831 .{ }^{22}$ An inscribed stele ${ }^{23}$ that formed an offering to Dionysus

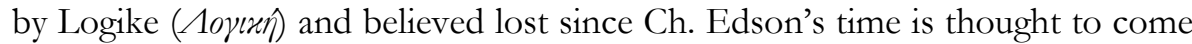
from Ano Komi. Therefore, the existence of a sanctuary dedicated to Dionysus at Ano Komi (Map 1, nr. 3), specifically at the site of "Profetes Elias", may be considered a possibility.

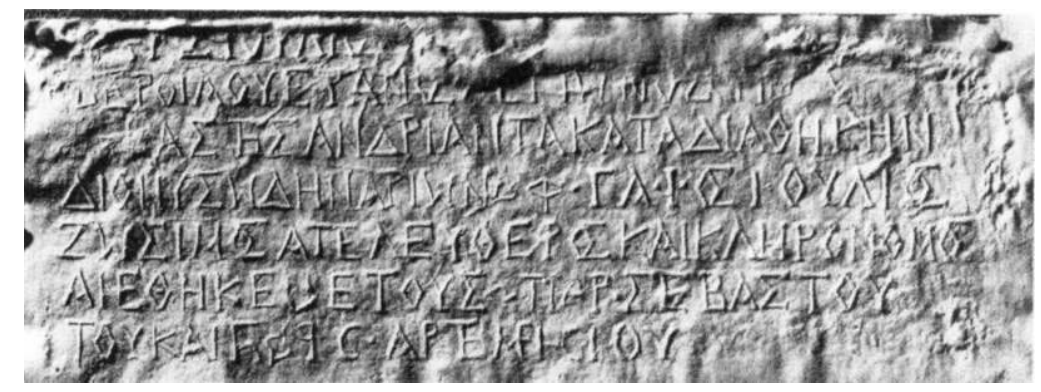

Fig. 9

\section{Zeus Hypsistos at Orestis and Lyncestis}

There was a significant sanctuary of Zeus Hypsistos on the hill of "Psalida" or "Vigla" or "Megalexandros" at Orestis in Kastoria (Map 1, nr. 4)24. At this site, which has been undergoing excavation since 1997, Zeus was worshipped along with Hera and Hermes from the late (?) Hellenistic period onward, as shown by statuettes and votive reliefs unpublished to date.

A sanctuary of Zeus Hypsistos is also located at Heraclea Lyncestis or in its surrounding area. This sanctuary remained active at least during the Roman period (Map 1, nr. 5) 25 as indicated by the portable finds on display today at the N.U. Institute and Museum of Bitola (Naroden Zavod Murej Bitola), which include: a) the lower part of a statuette of Zeus Hypsistos ${ }^{26}$ dating to 209/210

\footnotetext{
22 Rizakis, Touratsoglou (1985), p. 43-44 nr. 28, pl. 9 with previous bibliography. Cf. Chatzinikolaou (2007), Catalogue, nr. 135. This Roman fragment was later built into a Christian church in the area, before Ch. Edson's visit in 1937, and was later covered with mortar. According to a previous report, the fragment bore an inscription in which it was stated that it was a votive offering by Sextus, son of Petronius, in the wake of a dream.
}

${ }^{23}$ Rizakis, Touratsoglou (1985), p. 46 nr. 31, pl. 9 with previous bibliography. Cf. ChatZinikolaou (2007), Catalogue, nr. 133.

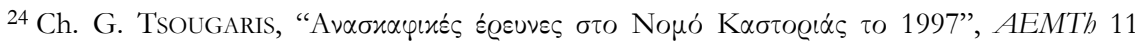

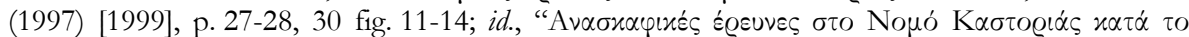

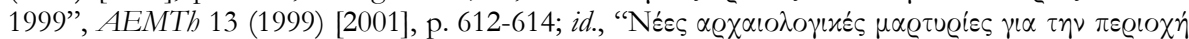

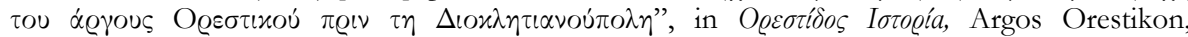
September 2000 (2001), p. 42; id., AD 52 (1997) [2003], Chron. B2, p. 744, 750. Cf. CHATZINI-

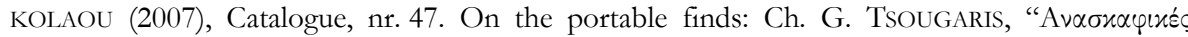

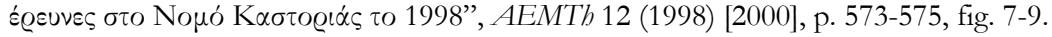

${ }^{25}$ Chrysostomou (1996), p. 55. Cf. Chatzinikolaou (2007), Catalogue, nr. 54.

${ }^{26}$ IG X 2.2, 63 with previous bibliography, KaLPakovskA, GjorgjIEvskA (2003), p. 24 nr. 4. Cf. Chatzinikolaou (2007), Catalogue, nr. 55. 
$\mathrm{AD}$; b) a statuette of an eagle from the second half of the $2^{\text {nd }}$ century $\mathrm{AD}, 27$ and c) the lower part of a votive relief from the early $3^{\text {rd }}$ century AD. ${ }^{28}$

\section{Apollo}

The figure of Apollo on the obverse of coins of the Elimiote Dynasty ${ }^{29}$ proves the significance of the cult of Apollo in the area. Apparently, this was a local Apollo cult dating back to the late Classical period. ${ }^{30}$

The remains of a sanctuary of Apollo ${ }^{31}$ (Map 1, nr. 6) and the two other gods probably co-worshipped there, Artemis and Dionysus (Fig. 10) ${ }^{32}$, were found at the site of "Porta" or "Portes" at Xirolimni, in the Prefecture of Kozani. A small section of the sanctuary came to light during excavations for the construction of the modern linking road for the Egnatia Odos (Fig. 11). The building complex cannot have been of monumental dimensions, which generally obtains for all sanctuaries in Upper Macedonia ${ }^{33}$. This site is identified with a sanctuary dedicated to the cult of Apollo on the basis of a large number of mostly fragmentary inscriptions and sculptures collected from the area. According to the excavators, the area of the sanctuary's building complex was dismantled and utterly destroyed over time, retaining only a very small section used in a later period. The sanctuary's location at an important crossing called "Porta", which connects Kozani to Mount Voion and Western Greece, made it significant.

27 Düll (1977), p. 357 nr. 166; Chrysostomou (1996), p. 55 nr. 2. Cf. Chatzinikolaou (2007), Catalogue, nr. 56.

${ }^{28}$ Düll (1977), p. 354 nr. 158, fig. 37; Chrysostomou (1996), p. 55 nr. 3. Cf. ChatzinikoLAOU (2007), Catalogue, nr. 57.

29 Liampi (1998), p. 8-11 nr. 9-17, pl. 2. Fr. Imhoof-Blumer, "Syrakosai-LysimachosDerdas", in Corolla Numismatica. Numismatic Essays in Honor of Barclay V. Head, London et al., 1906, p. 165-166. Cf. ChatziniKolaou (2007), Catalogue, nr. 72-73.

30 On the existence of Aiane's Mint: Liampi (1998), p. 6.

31 Karamitrou-Mentessidi (2000), p. 465-480; KARAMITROU-Mentessidi (2001a), p. 5859; KARAMITROU-MENTESSIDI (2001b), p. 337-345; KARAMITROU-MENTESSIDI (2002), p. 607610; G. Karamitrou-Mentessidi, AD 53 (1998) [2004], Chron. B2, p. 671. Cf. ChatzinikoLAOU (2007), Catalogue, nr. 79. The sanctuary and most of the finds remain largely unpublished.

32 A bronze figurine of Dionysus [Karamitrou-Mentessidi (2001b), p. 340, 363 fig. 2. Cf. ChatZinikOlaOU (2007), Catalogue, nr. 137] comes from Apollo's sanctuary at Xirolimni, where Apollo was co-worshipped with Artemis, whose presence is also attested epigraphically. The connection between Dionysus and Apollo is attested at Apollo's large sanctuaries. At Delphi, where Dionysus was also worshipped, his Maenads were called Thyiades. See W. OTTO, Dionysos, Paris, 1969 (French translation), p. 183-186. Dionysia had a great effect on Delos (M.P. NILSSON, Griechische Feste von religiöser Bedeutung mit Anchluß der attischen, Leipzig, 1906, p. 280-282), while the co-worship of Artemis and Dionysus is attested in various places, such as Corinth, where the statues of the two gods were erected together in the city's Agora (Pausanias, II, 2, 6), and Kalydon (E. Dyggve, Das Laphrion. Der Tempelbezirk von Kalydon, Kopenhagen, 1948, p. 297-301).

33 The same applies for Zeus' sanctuary at Petres in Eordaia (Map 1, nr. 1) 


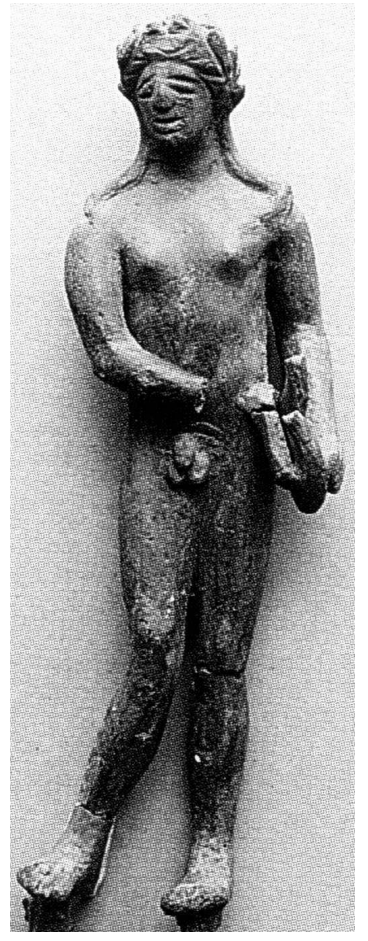

Fig. 10

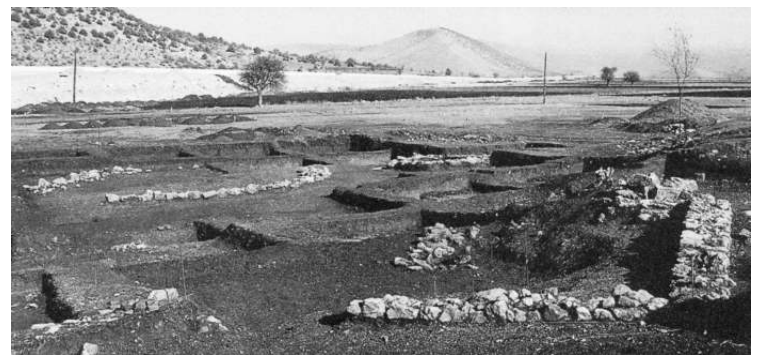

Fig. 11

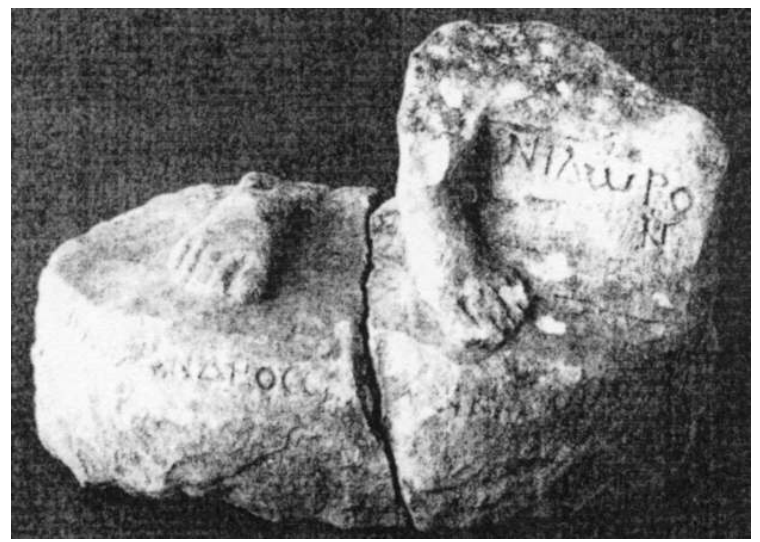

Fig. 12

Along with other portable finds ascribed to this sanctuary or its wider region there is a marble votive statuette (Fig. 12) ${ }^{34}$ and a marble inscribed votive stele ${ }^{35}$ informing us that Apollo was worshipped with the attribute Nomios (Nóuıs) there from at least the $2^{\text {nd }}$ century $\mathrm{BC}$, to which the stele is dated. We also learn that the sanctuary's influence exceeded the narrow geographical limits of Elimeia, since its dedicator was a certain Kleonikos (Kגعóvıxos) from Beroia.

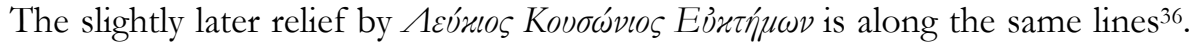
This is the first time Apollo is mentioned in Macedonia with the epithet

34 Karamitrou-Mentessidi (2001b), p. 343-344, fig. 9; Karamitrou-Mentessidi (2001a), p. 66-67 nr. 13, fig. 13. Cf. Chatzinikolaou (2007), Catalogue, nr. 80. This votive offering by Alexander and Philotera is a high-quality work dated to the second half of the $2^{\text {nd }}$ century AD.

35 Karamitrou-Mentessidi (2001a), p. 59-60 nr. 6, fig. 6; Karamitrou-Mentessidi (2001b), p. 341, fig. 5. Cf. CHATZinikOLAOU (2007), Catalogue, nr. 81.

36 G. Karamitrou-Mentessidi, AD 48 (1993) [1998], Chron. B2, p. 380-381; KaramiTROU-MENTESSIDI (2000), p. 466; KARAMitrou-MENTESSIDI (2001a), p. 62-63 nr. 9 , fig. $9 \alpha-\beta$. Cf. Chatzinikolaou (2007), Catalogue, nr. 82. It is not possible to determine the stele's precise find spot. It is dated between the $1^{\text {st }}$ century $\mathrm{BC}$ and the $1^{\text {st }}$ century AD. The name of the god may have been accompanied by a specific cult epithet, but the inscription is only fragmentarily preserved at that point. Apparently, the stele bore a depiction of Apollo. G. KaramitrouMentesidis' opinion on the written record Nopi $\omega$ in the third line of the inscription is very likely correct. 
Nomios, an attribute of Apollo known from the sources ${ }^{37}$ and related to the pastoral way of life. ${ }^{38}$

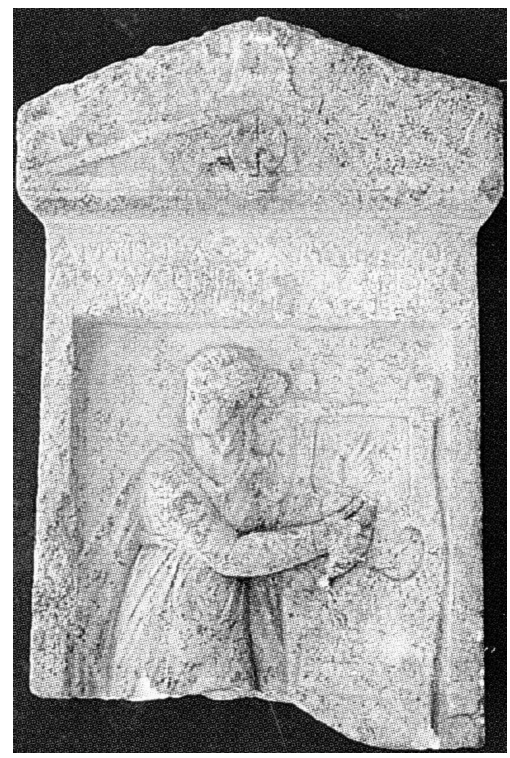

Fig. 13

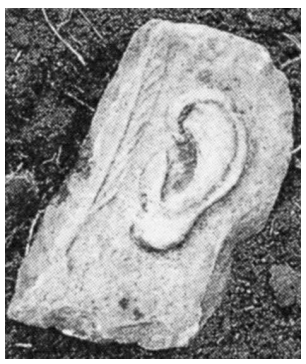

Fig. 16

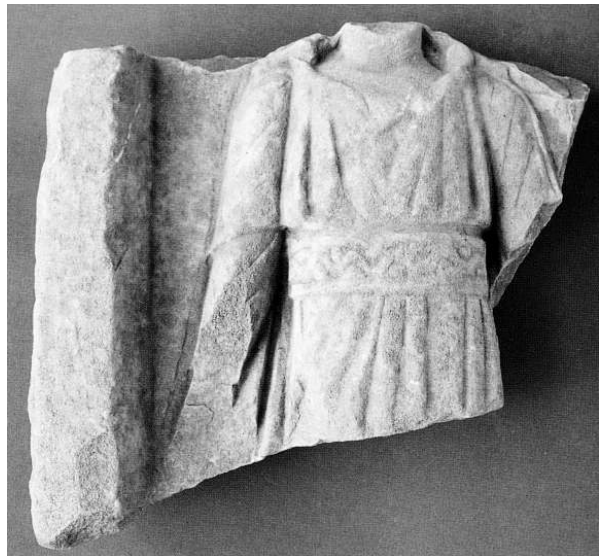

Fig. 14

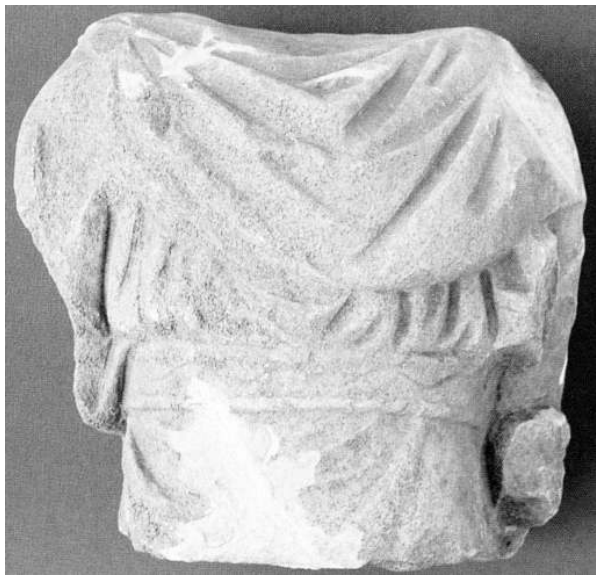

Fig. 15

There are other monuments (Fig. 13) 39 from the late Hellenistic and Roman periods from this sanctuary ${ }^{40}$ and dedicated to Apollo (Fig. 14-15), ${ }^{41}$ who bears

${ }^{37}$ Homer, Iliad II, 766; XX, 488. The god bears the same cult epithet in Thessaly: Euripides, Alcestis, 568-577.

38 KARAMITROU-MENTESSIDI (2001a), p. 59-60.

39 Karamitrou-Mentessidi (2001a), p. 61-62 nr. 7, fig. 7; Karamitrou-Mentessidi (2001b), p. 342 (fig. 6). Cf. CHATZINIKOLAOU (2007), Catalogue, nr. 83.

${ }^{40}$ KARAmitrou-Mentessidi (2001a), p. 62 nr. 8, fig. 8; KARAmitrou-Mentessidi (2001b), p. 342, fig. 7. Cf. Chatzinikolaou (2007), Catalogue, nr. 84. An omphalos is depicted on Apollo's right side and a tripod is probably on his left. These two symbols of the god refer to the Delphic sanctuary and are related to the cult's origins. See H.-V. Hermann, Omphalos, Münster, 1959. 


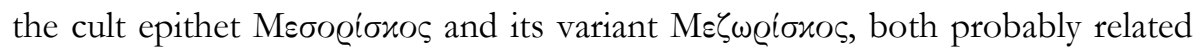
to a toponym. ${ }^{42}$ Apollo is depicted in the type of Citharoedus and it is fiarly certain that we can identify the same artisan or workshop that was probably active somewhere in the area. A relief from the Hellenistic-Roman period with a depiction of an ear from the site of the sanctuary at Xirolimni (Fig. 16) ${ }^{43}$ provides evidence of a dedication to Apollo, probably as an Epekoos ("who listens to prayers") deity.

It is speculated that there was a sanctuary of Apollo at the site "Kastro" at Mavropigi in Eordaia (Map 1, nr. 7), ${ }^{44}$ where there was a hillside settlement of the Hellenistic period. At this site, Apollo was worshipped with the cult epithet

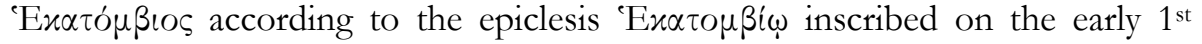
century BC marble votive stele showing Apollo Citharoedus holding a plectrum. ${ }^{45}$ The epithet ${ }^{~ E}$ E $\alpha \tau$ To $\beta \alpha \overline{i o s}$ from written sources is attributed to Zeus and Apollo, ${ }^{46}$ who have strong ties. This is the first attested use of this epithet for Apollo in Macedonia, which is known from inscriptions found in Southern Greece. ${ }^{47}$

Random finds from the Roman period, collected from sites in Eordaia and (primarily) Elimeia, bear depictions of Apollo Citharoedus and attest to his cult at Komanos $^{48}$ (Fig. 17), Tetralofos, ${ }^{49}$ and Velvendos ${ }^{50}$ in the Prefecture of Kozani.

${ }^{41}$ Karamitrou-Mentessidi (1999), p. 213, fig. 91-92; KArAmitrou-Mentessidi (2000), p. 466. KARAMitrou-MeNTESSIDI (2001a), p. 64-66 nr. 10-12, fig. 10-12; KARAMitrouMentessidi (2001b), p. 343, fig. 8. Cf. CHATZinikOlaOu (2007), Catalogue, nr. 85-89.

${ }^{42}$ Etymologically it probably refers to a location in the middle of the mountains. However, it may be related to specific attributes of the god. See KARAMITROU-MENTESSIDI (2001a), p. 67.

${ }^{43}$ Karamitrou-Mentessidi (2001b), p. 340, 363 fig. 4 (simple mention). Cf. ChatzinikoLAOU (2007), Catalogue, nr. 213, Chapter : Theoi Epēkooi, p. 264.

${ }^{44}$ Karamitrou-Mentessidi (1999), p. 255; Karamitrou-Mentessidi (2001a), p. 50 n. 5 , p. 51 n. 11; Karamitrou-Mentessidi (2001b), p. 344; Karamitrou-MENTESSIDI (2004), p. 275. Cf. ChatZinikolaou (2007), Catalogue, nr. 90. According to the excavators, illegal work involving leveling and possible damage by treasure hunters took place at the sanctuary's site.

45 M. Siganidou, AD 37 (1982) [1989], Chron. B2, p. 304; Karamitrou-Mentessidi (1990), p. 150-153, pl. 43; SEG 38 (1988), 665; Bull Épigr. 1990, 456; 1992, 380-381; ZIOTA, Karamitrou-Mentessidi (1991), p. 31. Cf. Karamitrou-Mentessidi (1993a), p. 76, 80-81 fig. 43; KARAMiTROU-MENTESSIDI (2001a), p. 50 n. 5, p. 51 n. 11 (simple mention); KARAMITROU-MENTESSIDI (2004), p. 275; ChatZiniKOLAOU (2007), Catalogue, nr. 91.

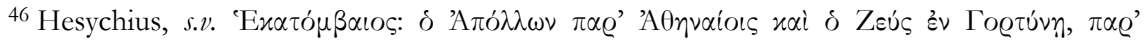

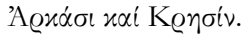

${ }^{47}$ Inscription from Mykonos with a reference to instituting feasts with sacrifices to the gods:

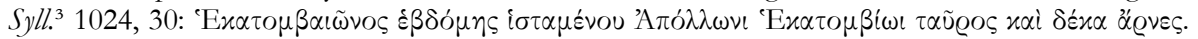
Cf. Karamitrou-Mentessidi (1990), p. 152.

48 Rizakis, Touratsoglou (1985), p. 98 nr. 100, pl. 37 with previous bibliography. Cf. Ziota, KARAMitrou-Mentessidi (1991), p. 28 and n. 7; KARAMitrou-Mentessidi (1993a), 78, 80-81 fig. 43 (simple mentions); CHATZINIKOLAOU (2007), Catalogue, nr. 77.

49 A. Andreiomenou, $A D 23$ (1968) [1969], Chron. B2, p. 350. Cf. KaramitrouMenTESSidi (1990), p. 151 n. 37; ChatZinikOlaOU (2007), Catalogue, nr. 75. 


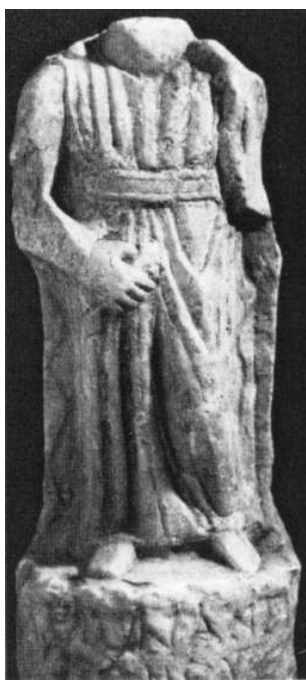

Fig. 17

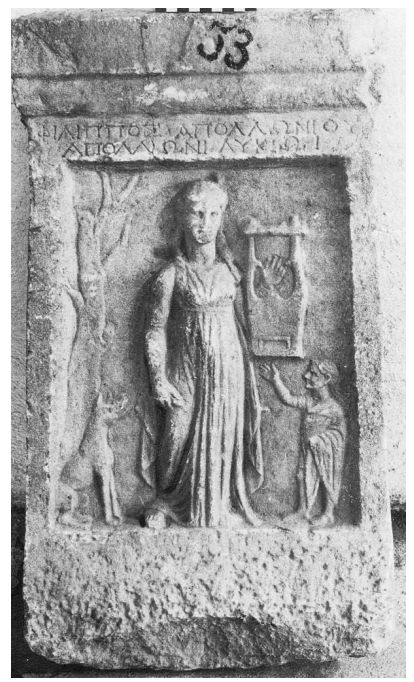

Fig. 18

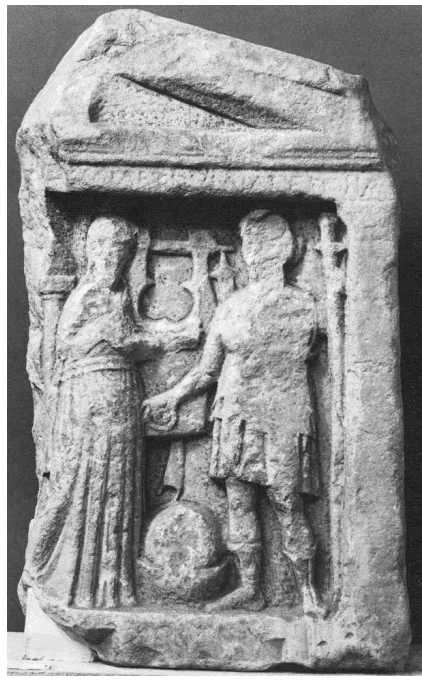

Fig. 19

The type of Apollo Citharoedus originated from the Archaic and above all the Classical period, from the Apollo Patroos ( $c f$. Athenian Agora Museum, Inv. Nr. S 2134), 51 but became more widespread from the Hellenistic period onward $^{52}$. In the Hellenistic votive stelae ${ }^{53}$ of Elimeia and Eordaia, Apollo is depicted wearing a high-girdled sleeved chiton with a wide belt and a himation draped over his back. This differentiates him from the type of Apollo Patroos, where Apollo wears the Attic peplos with a long overfold (apoptygma) ${ }^{54}$, and is characteristic of depictions of Apollo Citharoedus from the $4^{\text {th }}$ century BC onward, resembling related monuments of the Hellenistic period found in Macedonia like the votive relief to Apollo Lykios from Vergina ${ }^{55}$ (Fig. 18) and the votive relief to Apollo Pythios and Artemis Hegemone from Kalamoto in

${ }^{50}$ Karamitrou-Mentessidi (1994), p. 59-60, fig. 6. Cf. Chatzinikolaou (2007), Catalogue, nr. 76.

51 O. Palagia, Euphranor, Leiden, 1980, p. 13-25, fig. 6-17.

52 On the type and its development: M. Flashar, Apollon Kitharodos. Statuarische Typen der musischen Apollon, Köln, 1992.

${ }^{53}$ Usually these are stelae with an inscribed pediment. $C f$. the typological classification of funerary stelae from Upper Macedonia, particularly those from the Hellenistic period: RIZAKIS, TOURATSOGLOU (1993), p. 1288, 1297 plan 2.

${ }^{54}$ Flashar, o.c. (n. 52), p. 50-60.

${ }^{55}$ Chr. SaAtsoglou-Paliadeli, "A

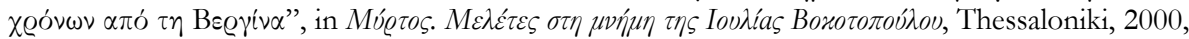
p. 441-451. Apart from the votive relief to Apollo Lykios, there is also a re-used votive stele with a depiction of Apollo Citharoedus and Artemis Kynegetis from Vergina, with a funerary inscription of the Roman period: ibid., p. 442 and n. 7-10 with previous bibliography. The same could be assumed for the relief of the Archaeological Museum of Beroia, Inv. Nr. $\Lambda$ 314, which preserves part of the depiction of a cithara player, but which bears a funerary inscription of the $2^{\text {nd }}$ or $3^{\text {rd }}$ century AD: EKM, nr. 412, pl. 631. 
Thessaloniki (the ancient Kalindoia) ${ }^{56}$ (Fig. 19). The type of Apollo Citharoedus of the Hellenistic and Roman monuments of Upper Macedonia stands on his stationary left leg while his right one is relaxed. He holds the cithara in his left hand and the plectrum in his right, in accordance with M. Flashar's classification of this type..$^{57}$

\section{Athena}

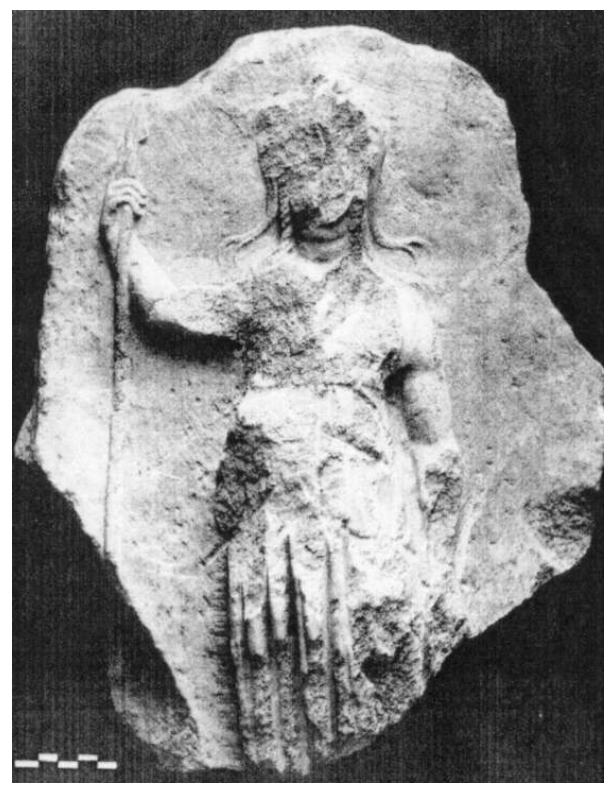

Fig. 20

An inscription ${ }^{58}$ is reported to have come from the area near the modern village of Bevi (or Vevi) in southern Lyncestis. This inscription, believed to be lost today, may have provided information about the founding or repair of a sanctuary of Athena in the area. The name of the epimeletes Antigonos who was probably the sanctuary's curator, is also mentioned. The meager data we possess for this inscription do not permit its secure dating.

It is certain that Athena must have been the object of a traditional cult in the region of Upper Macedonia. However, the decision to depict her wearing a Corinthian helmet on the obverse of bronze coins of the Fourth Meris (Fourth

Regional District) dating from 158 to $148 \mathrm{BC}^{59}$ can be considered politically motivated. In the reverse type of the same mint, the Dioskouri are depicted as horsemen with pointed piloi and spears and the inscription MAKE $\triangle O N \Omega N$ TETAPTH $\Sigma^{60}$. This particular mint is rather late evidence and a definite indication of a general cult to Athena. Perhaps the decision to depict Athena is

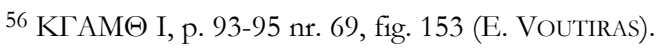

${ }^{57}$ Flashar, o.c. (n. 52), p. 81 nr. 30-44. Cf. Chr. SAatsoglou-Paliadeli, supra, p. 446.

${ }^{58}$ N. Giannopoulos, BCH 17 (1893), Chron., p. 635, according to an impression sent by the engineer M. Astima; Baege (1913), p. 32; Rizakis, Touratsoglou (1985), p. 166-167 nr. 182, pl. 71 (ambiguous). Cf. CHATZinikolaOU (2007), Catalogue, nr. 120.

${ }^{59} \mathrm{On}$ the mints of the Fourth Meris with depictions of Athena and Zeus, see CHATZINIKOLAOU (2007), Chapter: Zeus, p. 58-59.

${ }^{60}$ GAebler (1906), p. 61 nr. 187, pl. II.5; HeAd (1911), p. 238; GAeBler (1935), p. 7 nr. 42 , pl. III.7. Cf. DÜll (1977), p. 313-314 nr. 82; SCHumaCher (1996), p. 46, fig. 21; CHATZinikOLAOU (2007), Catalogue, nr. 115. 
related to political changes after Perseus' defeat and the guarantee of peace in combination with this region's autonomy during that period under the new regime.

Most depictions of Athena in this region are found in the form of reliefs, statuettes, and terracotta figurines ${ }^{61}$ belonging to the Hellenistic and Roman periods. They belong to, or reflect the Athena Parthenos type and are likely the creations of local workshops with common iconographical models (probably Attic) datable to the late $4^{\text {th }}$ century and early 3rd centuries BC. ${ }^{62}$ An illustrative example is the marble relief from Petres in Eordaia (Fig. 20), ${ }^{63}$ which is perhaps votive or taken from the sculptural decoration of a cult building (section "EBCE" in the plain south of the hill of the Hellenistic city of Petres) (Map 1, nr. 8)64, from the late $2^{\text {nd }}$ or early $1^{\text {st }}$ century BC. ${ }^{65}$ This relief was executed when the city was in its prime after the Roman conquest. Whether the place where it was found along with other evidence of cults reveals a sanctuary's existence outside the walls remains for the present a matter of speculation. ${ }^{66} \mathrm{~A}$ statuette of Athena (Fig. 21)67 from Bukovo, slightly south of Heraclea Lyncestis, now on display in the National Museum of Belgrade, dates to the first half of the

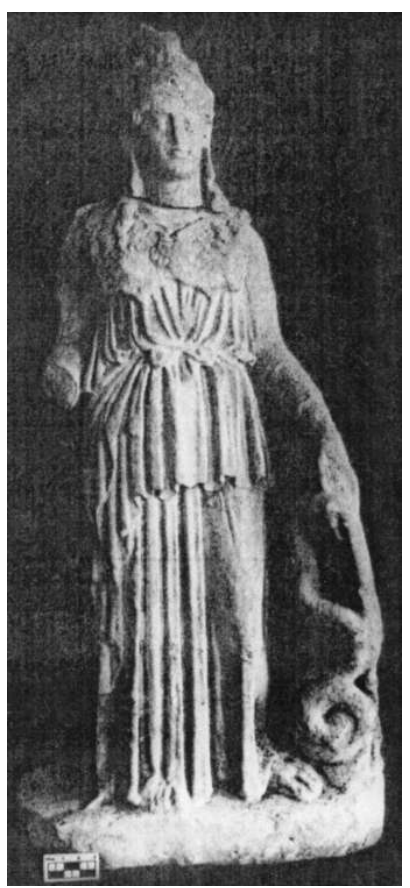

Fig. 21 $2^{\text {nd }}$ century AD. There are similarities between this statuette and the one depicting the Athena Varvakeios as regards the rendering of the head. Similar renderings exist in a series of statuettes of the Roman period which copy $5^{\text {th }}$ century BC statues of Athena, especially those of the Parthenos

${ }^{61}$ Karamitrou-Mentessidi (1989), p. 47 fig. 15; Karamitrou-Mentessidi (1996), p. 24, 46 fig. 32 (simple mentions). Cf. Chatzinikolaou (2007), Catalogue, nr. 117: Aiane, Hellenistic period.

62 On the discussion, see ADAM-VELENI (1987), p. 3-4.

63 AdAm-VELEnI (1987), p. 1-9, pl. 1; Voutiras (1998), p. 116-118, fig. 5. Cf. AdAm-VELENI (1997), p. 2; ADAM-VELENI (1998b), p. 28, 34 fig. 11 (simple mentions), CHATZINIKOLAOU (2007), Catalogue, nr. 118.

64 ADAm-VELENI (1988), p. 10; AdAm-VELENI (1997), p. 4 and n. 24; ADAM-VELENI (1998b), p. 36-38; Voutiras (1998), p. 116-117. Cf. Chatzinikolaou (2007), Catalogue, nr. 245.

65 ADAM-VELENI (1987).

66 Voutiras (1998), 117-118.

67 Vulić (1937), p. 21; Héraclée I (1961), p. 44 nr. 1, pl. 13 (P. MAČKIĆ, I. MikulČIĆ); DüLL (1977), p. 310-311 nr. 77, fig. 27; ADAM-VELENI (1987), p. 7 (simple mention). Cf. CHATZINIKOLAOU (2007), Catalogue, nr. 121. 
type. ${ }^{68}$ The votive relief of the second half of the $2^{\text {nd }}$ century AD from Prilep in Pelagonia ${ }^{69}$ and the statuette of Athena of the $3^{\text {rd }}$ century AD from the region of Sandanski ${ }^{70}$ fall typologically into the same group. Despite this evidence, the location of the sanctuary mentioned in the inscription from Bevi remains doubtful.

\section{Pluto}

Pluto is depicted frontally, horned and upright, wearing a himation and accompanied by Cerberus on a marble, temple-like, inscribed votive stele from Aiane in Elimeia dated to the $2^{\text {nd }}$ century AD (Fig. 22a-b)..$^{71}$ Titus Flavius Leonas' dedication to Pluto and the city of Aiane is stated in the first inscription (in a tabula ansata) on the stele's pediment. The process of dedication following the appearance of Pluto and his temple to the dedicator in a dream is described in a second inscription (above the depiction). The epithet $\Delta \varepsilon \sigma \pi \tau^{\tau} \eta \varsigma^{72}$ in the

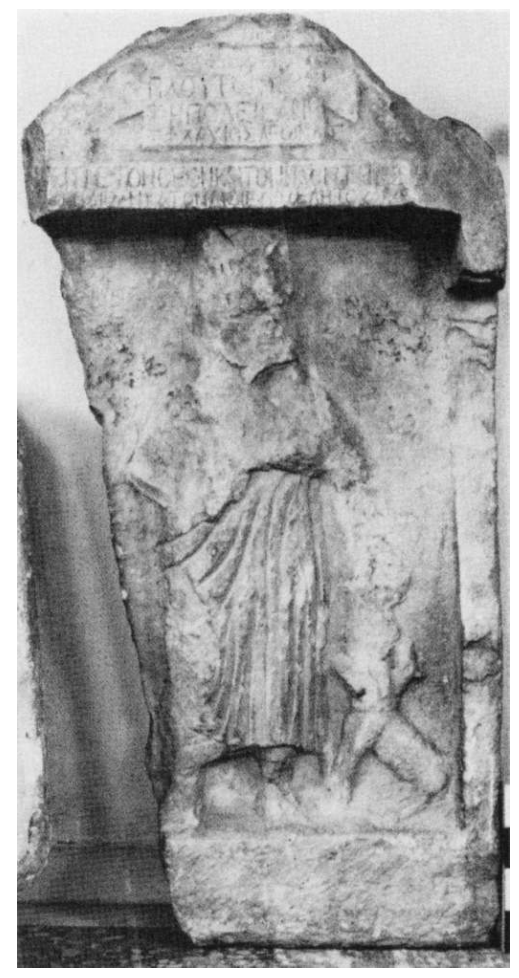

Fig. 22a

${ }^{68}$ According to P. KARANASTASSIS, "Untersuchungen zur kaiserzeitlichen Plastik in Griechenland. II: Kopien, Varianten und Umbildungen nach Athena-Typen des 5. Jhs. v. Chr.”, $M D A I(A) 102$ (1987), p. 326-339, production of copies of this type reached its height from late in the reign of Hadrian to the mid- $3^{\text {rd }}$ century AD. B. Schmidt-Dounas accepts this opinion for a series of such works in the Archaeological Museum of Thessaloniki: КГAM $\Theta$ II, p. 76-80 nr. 214-217 (B. SCHMIDT-DounAs) [see esp. Inv. nr. 214 (with ungirdled peplos) - Inv. nr. 215 for the comparison]. Also, see KГАM $\Theta$ I, p. 105 nr. 77, fig. 186-189 (G. DESPINIS), which provide iconographical and stylistic parallels for the statuette from Bukovo and also attest to the cult of Athena in the city and the area of Thessaloniki during the $2^{\text {nd }}$ and $3^{\text {rd }}$ centuries AD. Whether one should accept a date of the first or second half of the $2^{\text {nd }}$ century AD, as is suggested for the statuette (Inv. nr. 1160 of the Archaeological Museum of Thessaloniki)

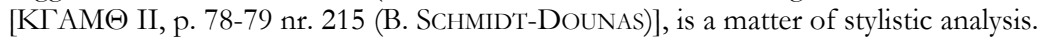

${ }^{69}$ DüLl (1977), p. 73, 314 nr. 83.

70 Ibid., nr. 84.

71 Rizakis, Touratsoglou (1985), p. 31-33 nr. 15, pl. 5 with previous bibliography; Rizakis, Touratsoglou (1999), p. 952, fig. 2-3. Cf. Karamitrou-Mentessidi (1989), p. 18; Karamitrou-MENTESSidi (1993b), p. 655; Sverkos (2000), p. 47 and n. 97; KARAmitrouMentessidi (2004), p. 272 (simple mentions); CHATZINIKOLAOU (2007), Catalogue, nr. 173.

72 BAEGE (1913), p. 141-142, correlates the inscription from Aiane to another inscription

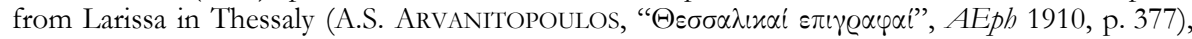
where Pluto is simply mentioned with the epithet Despotis along with the names of Demeter and

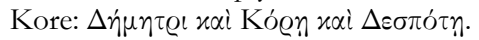


stele's inscription (line $1 \mathrm{a} / 1$ ) and attested once for Pluto in Macedonia, ${ }^{73}$ is

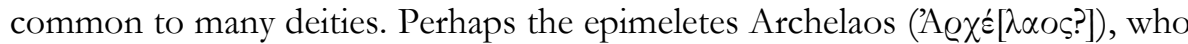

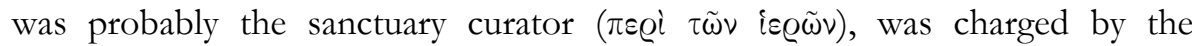
sanctuary with the monument's construction. ${ }^{74}$ The above-mentioned stele provides the only epigraphic evidence of the cult of Pluto and related ritual activities in Macedonia. It is inferred from the inscription's text that there must have been a temple with a cult statue in that area, perhaps in the type in which the god is depicted on the relief. ${ }^{75}$

The Christian church of Saint Athanasios, a dependency of the Zavordas Monastery, is located south-east of the modern settlement of Aiani. Several of its building materials come from an ancient construction. It is very likely that K. Siampanopoulos was correct in assuming that there was a sanctuary of Pluto and probably an enkoimeterion (incubation room) (Map 1, $n r .9)^{76}$ at this site, from which

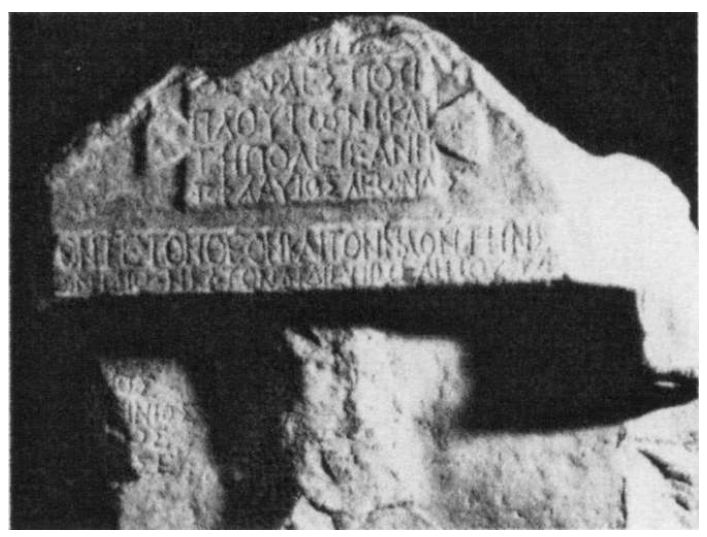

Fig. 22b the stele and several architectural members incorporated into the dependency's buildings come. This chthonic god's cult in Upper Macedonia is one of the very few cases of peculiarities that are useful more for drawing conclusions about this region's cultural relations with its neighbours, where there were sanctuaries of HadesPluto, and less for the cult itself, which does not seem to have been particularly widespread. The fact that the evidence for the cult and the sanctuary are dated later may be attributed to Roman influences.

73 On Pluto's cult in Macedonia and especially at Aiane, see L. HeUZEY, RA 18 (1868), p. 18 -

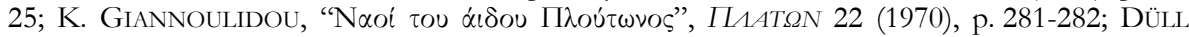
(1977), p. 118; Rizakis, Touratsoglou (1999), p. 952 n. 13. Cf. Rizakis, Touratsoglou (1985), p. 32.

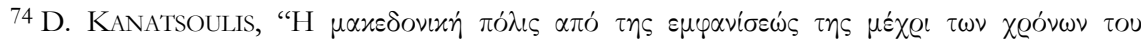

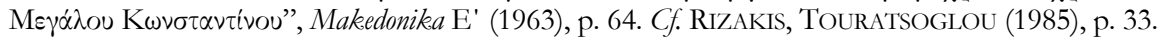

75 This statuary type most likely refers to well known types from Attica and Koroneia in Boeotia, where the god's cult is attested. See PAPACHATZIS (1987), 116-117, fig. 114.

76 Siampanopoulos (1974), p. 123-126. Cf. A.Tsilipakou, AD 52 (1997) [2003], Chron. B2, p. 789-790; CHATZINIKOLAOU (2007), Catalogue, nr. 172. 


\section{Hecate - Enodia}

In the passages of Upper Macedonia's mountainous areas, female deities with similar attributes, such as Hecate (Map 1, nr. 10, Fig. 23) ${ }^{77}$ and above all Enodia, were among the traditional deities with a dark and apotropaic character, such as Pluto.

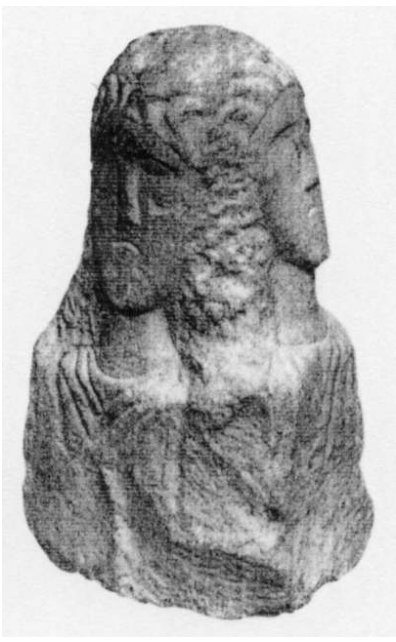

Fig. 23

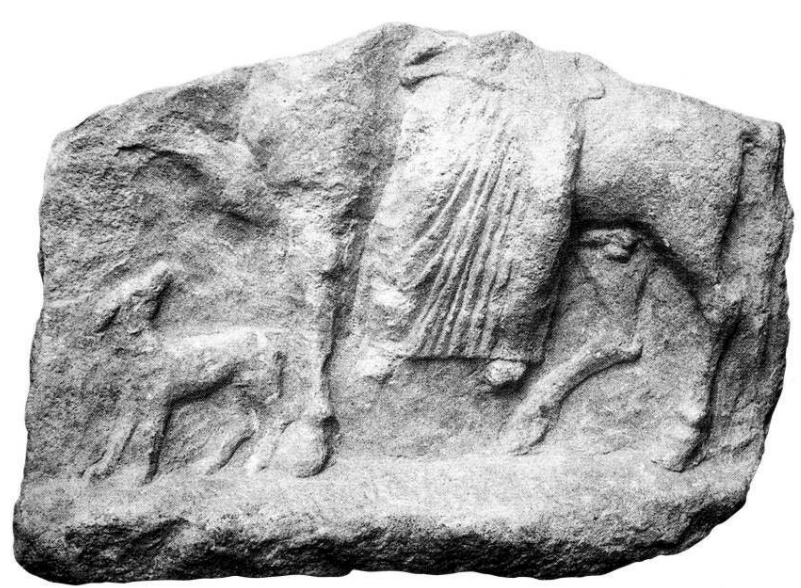

Fig. 24

There was a sanctuary of Enodia at Exochi in Eordaia (Map 1, nr. 11) ${ }^{78}$ which was active from the second half of the $2^{\text {nd }}$ century $\mathrm{BC}$, the date of the earliest evidence, until the Roman period. The modern settlement of Exochi has been abandoned by its inhabitants. However, architectural members, inscribed relief stelae, and coins from a sanctuary of Enodia which must have been close to Exochi or near Mount Vermion's western foot, began to come to light and have been collected since 1959, as a result of intensive mechanical farming of the area's fields. The material remains, which were not found in situ, lead to the conclusion

${ }^{77} \mathrm{~A}$ rural sanctuary with the cult of this female goddess or even Enodia and perhaps other deities may be sought at the site "Gortsia" or "Diakladosi" (intersection) at Liknades on Mount Voion, located in the southern part of Orestis: CHATZINIKOLAOU (2007), Catalogue, nr. 169. P. Chrysostomou mentions that an ancient cemetery is located at this site and speculates about a sanctuary's existence there. On the location and possibility of the existence of ancient sanctuaries: Chrysostomou (1998), p. 176 nr. 7; Karamitrou-Mentessidi (1999), p. 153, 201, 202, 345 346 fig. 69, 72. A Hekataion from the Hellenistic period comes from this site: CHRYsOsTOMOU (1998), supra; Karamitrou-Mentessidi (1999), p. 201 and n. 608, fig. 71. Cf. ChatzinikOLAOU (2007), Catalogue, nr. 170.

78 G. DAUX, BCH 83 (1959), p. 697; L. RoberT, Hellenica XI-XII (1960), p. 589; G. KarAmItrou-Mentessidi, AD 38 (1983) [1989], Chron. B2, p. 307-309; Chrysostomou (1998), p. 72 82. Cf. Karamitrou-Mentessidi (1993a), p. 92 (simple mention), Nigdelis, Souris (1996), p. 69-70; CHATZINIKOLAOU (2007), Catalogue, nr. 154. 
that this sanctuary had a small temple, at least during the Roman period. Its destruction should be dated to Late Antiquity and is probably attributable to the followers of Christianity. ${ }^{79}$ Its material remains were scattered and after the sanctuary's destruction the neighbouring area was banked up with earth during Antiquity to enable cultivation. ${ }^{80}$ The following finds come from the site of Exochi and may be connected with this sanctuary: inscribed architectural members, inscribed and uninscribed votive reliefs, and stelae.

The type constantly appearing in the iconography of Enodia in Upper Macedonia from the Hellenistic until the late Roman period ${ }^{81}$ is depicted in the early $3^{\text {rd }}$ century $\mathrm{AD}$ marble votive relief from the area south of the Christian church of Saint Paraskevi in Elimeia (the modern village of Hagia Paraskevi) (Fig. 24).82 It has a depiction of Enodia sitting sideways on a horse, holding a short torch and with a dog accompanying her. An inscribed marble votive stele from the Archaeological Collection of Kozani (Fig. 25) 83 is dated between the $2^{\text {nd }}$ and $1^{\text {st }}$ century BC. It provides epigraphic testimony, and depicts an iconographic type of Enodia standing in three-quarter view, hold-

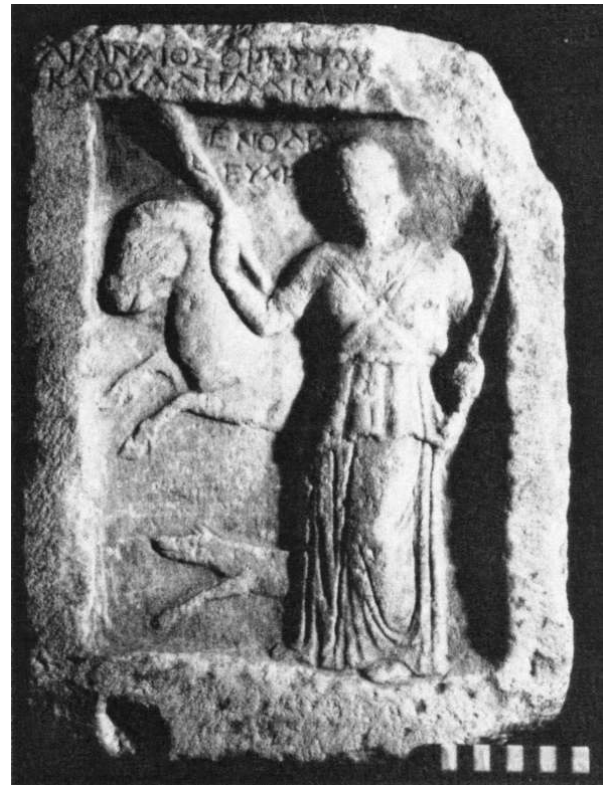

Fig. 25

${ }^{79}$ Chrysostomou (1998), p. 82 and n. 259: surmising that the destruction should be dated between 379 and $395 \mathrm{AD}$ and attributed to the followers of the new religion based on the coins of Theodosius I found at the site. Several sanctuaries in the countryside and some temples in the cities were looted and destroyed under the guidance of the Praefectus of the East, Maternus Kynegius from Spain, between 384 and 388 AD.

${ }^{80}$ Ibid., p. 82. There is a similar case at Palaiopolis in Corfu. See PAPACHATZIS (1987), p. 208.

${ }^{81}$ I. Touratsoglou and N.G.L. Hammond dated the relief to the Roman Imperial period in general and interpreted this figure as Artemis or Hecate Hepone. P. Chrysostomou considers this figure to be Enodia of Pherai and believes that there must have been a sanctuary of Enodia in the area. His remarks on the formation of the goddess' iconographical type and possible regional variations should probably be confined to ascertaining the existence of different artists or artistic tendencies. Regarding opinions formed from research, see the following note.

${ }^{82}$ I.P. Touratsoglou, AD 24 (1969) [1970], Chron. B2, p. 333, pl. 341є; Hammond, GrifFITH (1979), p. 165 n. 3; L. KAHIL, N. ICARD, s.v. "Artemis", LIMC II, 1, (1984), p. 688, nr. 885c; Chrysostomou (1998), p. 83, 149-150, pl. 14 $\alpha$. Cf. Chatzinikolaou (2007), Catalogue, nr. 153.

83 Rizakis, Touratsoglou (1985), p. 93 nr. 94, pl. 34 with previous bibliography; CHRYSOstomou (1998), p. 74-75, pl. 14ß. Cf. KARAMITROU-MENTESSIDI (1993a), p. 78, 80-81, fig. 44 (simple mention); CHATZINIKOLAOU (2007), Catalogue, nr. 155. 
ing short torches and wearing a sleeved chiton poderes, which is cross-girdled under the chest. The stele features depictions of a horse and a dog on a second level. It was found abandoned in a modern dwelling in Ptolemaida and it is not certain that it comes from Exochi. The small marble inscribed altar-censer (Fig. 26) ${ }^{84}$ from Exochi and dated to the $2^{\text {nd }}$ century $\mathrm{AD}$ is an offering by Nikandros with relief depictions of dogs and crescent moons on its three sides. 85
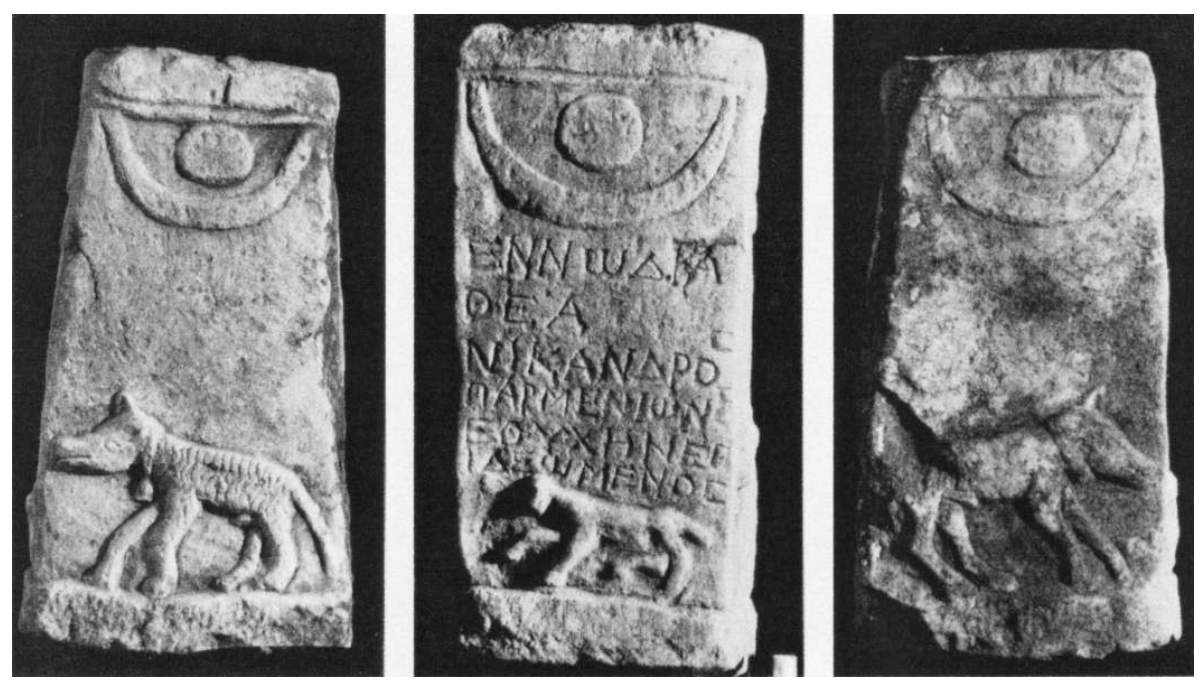

Fig. 26

Enodia's name is accompanied by the definition "goddess", thus showing that Enodia was a foreign deity who came to Macedonia, like Dea Syria, the Cappadocian goddess Ma, the Phrygian goddess Nemesis, and the Mother of the Gods. ${ }^{86}$ Censers $^{87}$ were frequent offerings to Enodia, e.g. the inscribed marble censer, resembling a handless oval-shaped vase, which was a votive offering by Zosas to Enodia from Exochi dating between the $2^{\text {nd }}$ and the 3 rd

84 Rizakis, Touratsoglou (1985), p. 96-97, nr. 98, pl. 36 with previous bibliography; Chrysostomou (1998), p. 76-77. Cf. Ziota, Karamitrou-Mentessidi (1991), p. 28 and n. 7 (simple mention); CHATZINIKOLAOU (2007), Catalogue, nr. 156.

85 Chrysostomou erroneously interprets the animal on the front as a hare, and the crescent moons as garlands. He believes that the images on the three sides depict a hare hunt with the two dogs on the sides advancing towards the animal on the front. This is a rather far-fetched interpretation. Most likely, the figure depicted is a dog; judging from its anatomy, it cannot be identified as a hare. On the related discussion, see CHATZINIKOLAOU (2007), Catalogue, nr. 156.

86 See also Chrysostomou (1998), p. 77.

87 The offering of incense, requisite in most sacrifices, was usually accompanied by a prayer. On this subject: W. W. MüLlER, s.v. "Weihrauch", RE Suppl. XV, 1978, p. 756. Cf. RIZAKIS, Touratsoglou (1985), p. 97, nr. 98, pl. 36; A. MoustakA, s.v. "Enodia”, LIMC III, 1 (1986), p. 744; Chrysostomou (1998), p. 76 n. 239. 
century AD (Fig. 27). ${ }^{88}$ Another votive offering from this sanctuary is the inscribed marble relief of the second half of the $2^{\text {nd }}$ century $\mathrm{AD}$, a votive

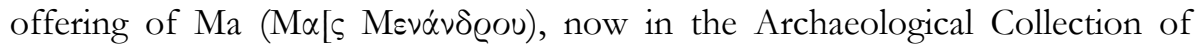
Kozani (Fig. 28). ${ }^{89}$

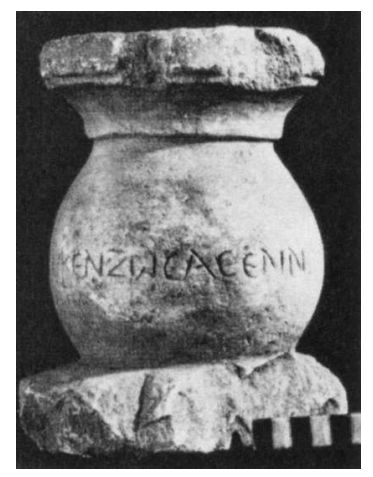

Fig. 27
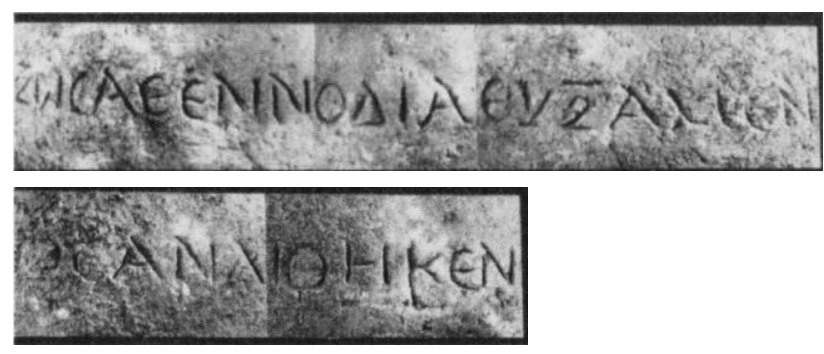

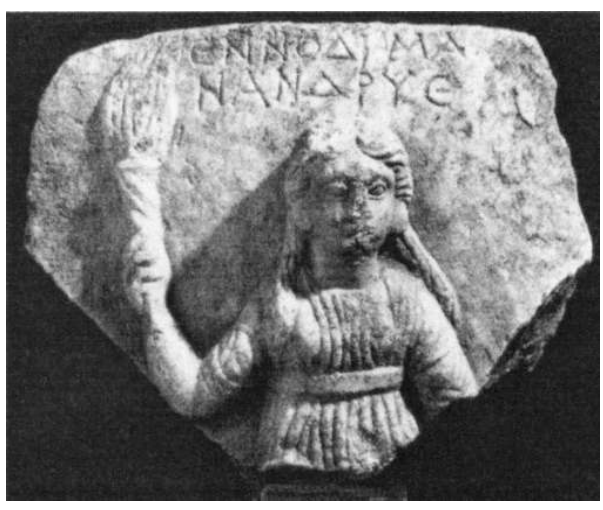

Fig. 28

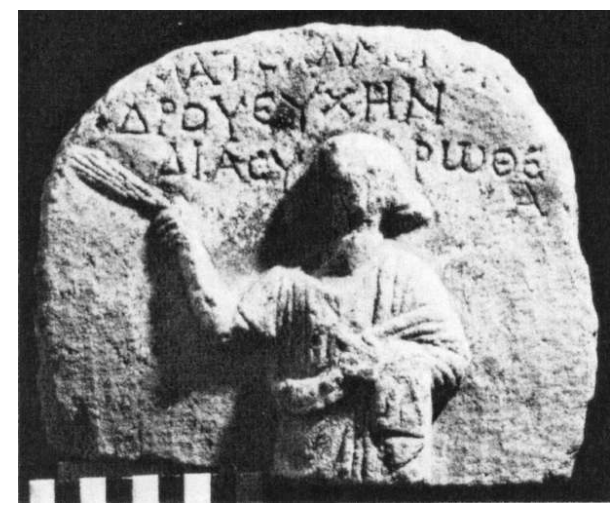

Fig. 30

Most of the horizontal component of a marble inscribed offering table from the sanctuary of Exochi was found in detached but adjoining parts in 1958 and 1983..$^{0}$ The inscription's publishers dated it to the first half of the $3^{\text {rd }}$ century AD. Pieces of fragments lead to the conclusion that it is an offering by a

${ }^{88}$ Rizakis, Touratsoglou (1985), p. 99 nr. $100 \alpha$, pl. 37 with previous bibliography; Chrysostomou (1998), p. 77-78, pl. $11 \gamma$ - $\delta$. Cf. Ziota, Karamitrou-Mentessidi (1991), p. 28 and n. 7 (simple mention); CHATZINIKOLAOU (2007), Catalogue, nr. 158.

${ }^{89}$ Rizakis, Touratsoglou (1985), p. 97-98 nr. 99, pl. 36 with previous bibliography; Chrysostomou (1998), p. 75-76. Cf. Ziota, Karamitrou-Mentessidi (1991), p. 28 and n. 7; Chrysostomou (1992), p. 105 and n. 10, KARAMitrou-MENTESSIDI (1993a), p. 91,92 fig. 49 (simple mentions); CHATZINIKOLAOU (2007), Catalogue, nr. 157.

${ }^{90}$ Rizakis, Touratsoglou (1985), p. 103 nr. 105, pl. 39, fig. 105 with previous bibliography, Chrysostomou (1998), p. 81 and n. 252. Cf. G. Karamitrou-Mentessidi, AD 38 (1983) [1989], Chron. B2, p. 307; Ziota, KARAMitrou-Mentessidi (1991), p. 28 and n. 7; CHATZINIKOLAOU (2007), Catalogue, nr. 159. 


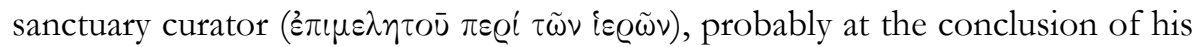
service. The inscription also provided the date, which unfortunately has not been preserved.

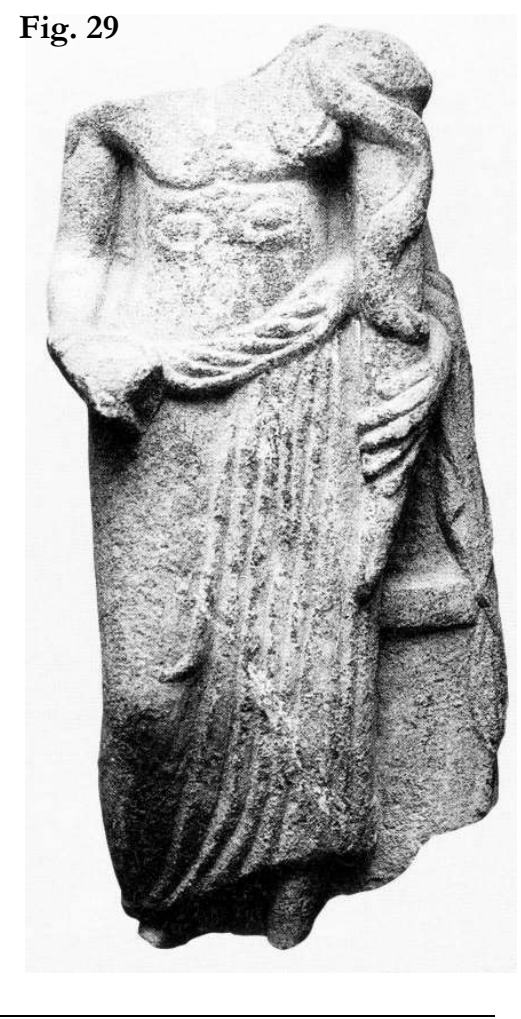

The sanctuary's votive offerings are complemented today by a series of marble reliefs in the Archaeological Collection of Kozani and reflecting a common iconographical type of Enodia which seems to have been used in the depictions of votive offerings from the late $2^{\text {nd }}$ to the third quarter of the $3^{\text {rd }}$ century AD. ${ }^{91}$

Enodia was worshipped in the regions near Thessaly, where her cult spread via natural crossroads ${ }^{92}$. She was possibly coworshipped with Zeus Meilichios ${ }^{93}$ in the sanctuary of Exochi from the Hellenistic period, as attested by the statuette of Zeus Meilichios (Fig. 29)94 and a coiled snake. ${ }^{95}$ It is possible that Dea Syria was also worshipped in the same place since two marble votive reliefs of the $2^{\text {nd }}$ and $3^{\text {rd }}$ centuries AD depicting the goddess from the site of the sanctuary of Enodia at Exochi in Eordaia have been found (Fig. 30). ${ }^{96}$ Both are now in the Archaeo-

${ }^{91}$ Chrysostomou (1998), p. 147-149 and n. 540, pl. 13 with previous bibliography. Cf. Karamitrou-Mentessidi (1993a), p. 90, 92 fig. 49 (simple mention); ChatZiniKOlaOU (2007), Catalogue, nr. 163-167. These are probably the works of a local artist, perhaps Ariston, who was working in Eordaia and Elimeia at that time.

${ }^{92}$ Her cult is attested from the $3^{\text {rd }}$ century BC in the neighbouring Perraivian Tripolis. See Chrisostomou (1998), p. 82 and n. 263.

${ }^{93}$ Co-worship of these two hard to appease chthonic goddesses is also attested at the small sanctuary of Enodia in the west cemetery of Pherai in Thessaly. See Chrysostomou (1998), p. 235 with relevant bibliography.

${ }^{94}$ Chrysostomou (1998), p. 235 and n. 911, pl. $33 \alpha$. Cf. Chatzinikolaou (2007), Catalogue, nr. 59.

95 G. Karamitrou-Mentessidi, AD 38 (1983) [1989], Chron. B2, p. 307; P. Chrysosto-

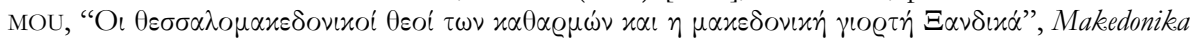
29 (1993-94) [1994], p. 185; Chrysostomou (1998), p. 235 and n. 910. Cf. Chatzinikolaou (2007), Catalogue, nr. 60.

${ }^{96}$ Rizakis, Touratsoglou (1985), p. 100-101 nr. 102, pl. 38 with previous bibliography. $C f$. Chrysostomou (1992), p. 104 and n. 9, fig. 4, 105 and n. 11, fig. 5; KARAMitrou-MeNTESSIDI (1993a), p. 91, 92 fig. 49 (simple mentions); Chatzinikolaou (2007), Catalogue, nr. 237-238. On the first relief (Fig. 30), the goddess is depicted in frontal view standing and holding a sheaf of ears. She is mentioned as Diasyros Thea in the inscription's text. However, the possibility that she 
logical Collection of Kozani. Manumission acts ${ }^{97}$ have been traced on architectural members of the sanctuary at Exochi. Manumissions of slaves to Enodia are attested only at her sanctuary at Exochi.

\section{Artemis Ephesia}

There is a mother-like entity with the name of the goddess Artemis that functions similarly as regards the acceptance and guarantee of manumissions. Artemis Ephesia ${ }^{98}$ is a variant of the same great female deity that predominated in the East and was identified with many goddesses of the Greek world, above all with Artemis in the form of primitive nature goddess rather than agile huntress. Artemis Ephesia came back when Eastern elements entered the Greek mainland.

In inscribed votive reliefs from the sites of North Lyncestis, near Heraclea Lyncestis, Artemis is depicted surrounded by two male figures standing in front of their horses who may be identified with the Dioskouri ${ }^{9}$ in their most commonly depicted type, "au service d'une déesse", 100 where they are merged with the representatives of the company of men attending the great Eastern goddess.

The marble inscribed relief ${ }^{101}$ of the $2^{\text {nd }}$ century AD comes from Živojino, which lies south-east of Bitola in North Lyncestis. Two manumission inscriptions and dedicated to Artemis Ephesia and dated to 204/205 AD, now in the N.U. Institute and Museum of Bitola (Naroden Zavod Muzej Bitola), were carved

was depicted sitting on a fish, as in a relief from Demetrias, cannot be excluded. Cf. ChrysostoMOU (1992), p. 104. The second relief, which bears no inscription, depicts the goddess sitting sideways on a cetacean or a fish. The literary sources mention depictions of the goddess in the

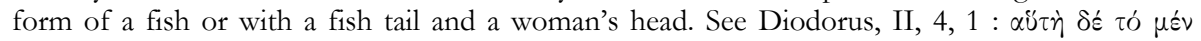

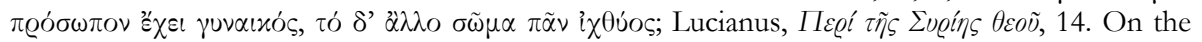
correlation of the cult with the fish, $c f$. CHRYSOSTOMOU (1992), p. 109-110 with bibliography.

${ }^{97}$ Rizakis, TOURATSOglou (1985), p. 112-116 nr. 116-117 $\alpha-\beta$, pl. 43-44 with previous bibliography; SEG 35 (1985), 638-639, 747, E. VOUTIRAS, Zu zwei makedonischen Freilassungskunden, Tyche 1 (1986), p. 233-243; Nigdelis, Souris (1996), Chrysostomou (1998), p. 78-81. Cf. ChatZiniKolaou (2007), Catalogue, nr. 159-162.

98 On Artemis Ephesia: R. FLeISCHER, Artemis von Ephesos und verwandte Kultstatuen aus Anatolien und Syrien, Leiden, 1973 (EPRO, 35); id., s.v. "Artemis Ephesia", LIMC 2 (1984), p. 755-763. On her cult in the northern regions of Macedonia: DÜll (1977), p. 66-68; CHATZINIKOLAOU (2007), Chapter: Artemis (Ephesia), p. 135-139.

${ }^{99}$ S. Eitrem, Die göttlichen Zwillinge bei den Griechen, Oslo, 1902; A. Hermary, s.v. "Dioskouroi", LIMC III (1986), p. 578-580. There were votive reliefs to the Dioskouri at sites in Pelagonia and Stobi during the Roman Imperial period. See DÜLL (1977), p. 374-379 nr. 201-202, 204-206, fig. 57, 59, IX.

100 CHAPOUTHIER (1935).

${ }^{101}$ IG X 2.2, 9, pl. II with previous bibliography. Cf. A. Hermary, s.v. "Dioskouroi", LIMC III (1986), p. 578 nr. 136; CHATZINIKOLAOU (2007), Catalogue, nr. 118. 
on a marble stele from Heraclea Lyncestis. ${ }^{102}$ It is reported that a lost Ionic column with a votive inscription to Artemis dated to the $3^{\text {rd }}$ century AD came from the modern village of Vašarejka north-east of Bitola, according to the publishers of IG. ${ }^{103}$ Perhaps this is another region where Artemis Ephesia was worshipped despite the fact that she is not mentioned with this cult epithet in the inscription from Vašarejka in North Lyncestis. According to the text, Aurelius Iulianus dedicated the column that may have supported a statue of Artemis, which is not preserved, in memory of his wife Amia. W. Baege assumed that the object was in a temple of Artemis in that area (Map 1, nr. 12), a view with which S. Düll ${ }^{104}$ and F. Bömer ${ }^{105}$ concur.

Artemis Ephesia seems to have been very popular in the neighbouring regions north of Lyncestis since her name is attested in two votive inscriptions of the $2^{\text {nd }}$ and $3^{\text {rd }}$ century $\mathrm{AD}$ in the region of Stobi ${ }^{106}$, while the kome Kolovaissa ${ }^{107}$ is attested in a manumission inscription dated to the early $3^{\text {rd }}$ century $\mathrm{AD}$ and found at the sanctuary of the goddess in Pelagonia. ${ }^{108}$

\section{Passikrata}

Evidence for the cult of Passikrata in Upper Macedonia comes from Suvodol, on the border between Pelagonia and Lyncestis where a sanctuary of Passikrata should be sought. Three manumission inscriptions with dedications by slaves to the goddess and a reference to the goddess' feasts in the area were carved on a marble quadrangular altar. ${ }^{109}$ Although the three inscriptions are not dated to the same time, they all date between the late $2^{\text {nd }}$ and early $3^{\text {rd }}$ century $\mathrm{AD}$, as stated in their texts. The village (kome) mentioned in the inscription a/ line 4 should be identified with a site within the borders of Heraclea Lyncestis, according to F. Papazoglou. ${ }^{110}$ It may come from a village near modern Suvodol, situated east of Heraclea ${ }^{111}$ (Map 1, nr. 13). The

\footnotetext{
102 Kalpakovska, Gjorgjievska (2003), p. 28-29 nr. 11, difficult to read. Cf. ChatzinikoLAOU (2007), Catalogue, nr. 112.

${ }^{103}$ IG X 2.2, 34, pl. VI with previous bibliography. Cf. CHATZINIKOLAOU (2007), Catalogue, nr. 111.

104 DÜlL (1977), p. 306 nr. 73.

105 F. BÖMER, Untersuchungen über die Religion der Sklaven in Griechenland und Rom II, Wiesbaden, 1960, n. 1. Cf. IG X 2.2, 34.

106 DüLL (1977), p. 288-289 nr. 36, p. 303 nr. 67.

107 On Kolovaissa: Papazoglou (1988), p. 291; Sverkos (2000), p. 35.

108 N. Vulić, "Inscriptions grecques de Macédoine”, AIPhO 4 (1938), p. 343; DüLl (1977), p. $291 \mathrm{nr} .40$, IG X 2.2, 233. Cf. SverKos (2000), p. 35.

${ }^{109} I G \times$ X 2.2, 18, pl. III with previous bibliography. Cf. Sverkos (2000), p. 36, 94, 96-97; ChatZinikolaOU (2007), Catalogue, nr. 171.

110 Papazoglou (1988), p. 372 and n. 104.

111 SVERKOS (2000), p. 94.
} 
Thessalian Passikrata is a goddess with chthonic characteristics, identified with chthonic attributes of Aphrodite. ${ }^{112}$ During hard times, believers sought the favour of the goddess, ${ }^{113}$ who was sometimes identified with Kore ${ }^{114}$ and at others with Artemis. ${ }^{115}$ However, this is a case of a $\pi \alpha \sigma \varkappa \varrho \alpha ́ \tau \eta$ (universal, "allruling”) goddess.

\section{Herakles}

The cult of Herakles has an older tradition in Elimeia, as is proven by his depiction on the obverse of coins from the Derdas bronze mint of the first half and perhaps the mid$4^{\text {th }}$ century BC. ${ }^{116}$

Marble inscribed votive stelae have come from Ryakio in Eordaia, where research suggests the existence of a sanctuary dedicated to Herakles Kynagidas (Map 1, nr. 14). ${ }^{117}$ One of these stelae is an old find kept in the Archaeological Collection of Kozani and provides the only depiction of the god's statuary type, possibly that of his cult statue

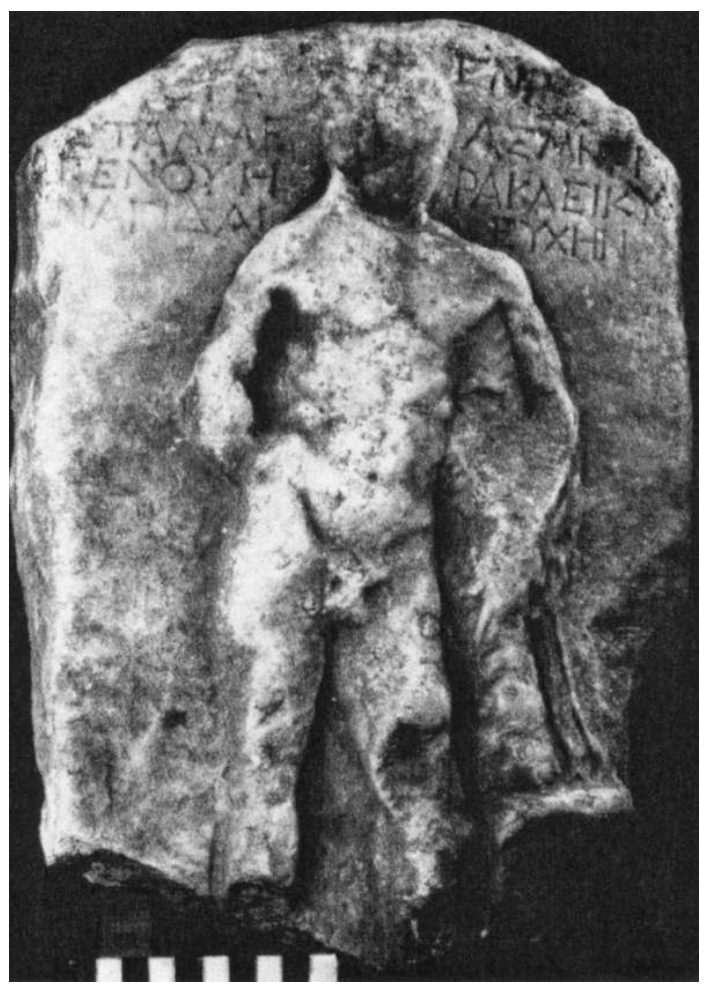

Fig. 31

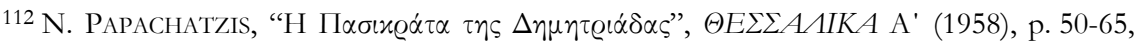
believes that Passikrata (the Aphrodite of the Dead) and Artemis Enodia, who is identified with Enodia of Pherai by the same author, were worshipped in the funerary and roadside sanctuary of the south cemetery of Demetrias. Cf. CHRYsostomou (1998), p. 95-96.

113 On her cult in Macedonia: DüLL (1977), p. 116-118.

114 The epithet Passikrata or Passikrateia is attributed to Persephone: Homer, Hymn to Demeter, 365. It is also attested in an inscription of the $5^{\text {th }}$ century BC at Selinous: IG XIV, 268. Cf. SimON (1996), p. 108.

115 The cult epithet Passikrata accompanies Artemis' name in dedicatory inscriptions from Ambrakia and Thesprotia in Epirus. See K.A. RomAIOS, AD 2 (1917), Annex 1916, p. 52-53;

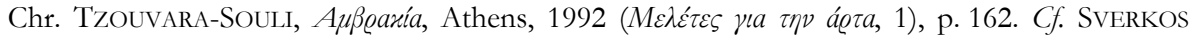
(2000), p. 95 and n. 330.

116 LiAmpi (1998), p. 9-10 nr. 18, pl. 2. Cf. ChatzinikolaOU (2007), Catalogue, nr. 181.

117 Chr. Ziota, AD 50 (1995) [2000], Chron. B2, p. 584 (simple mention). Cf. CHATZINIKOLAOU (2007), Catalogue, nr. 195. 
(Fig. 31).118 The depiction recalls the Copenhagen/ Dresden type that reflects an original of the $360 \mathrm{~s} \mathrm{BC}$; it is the predecessor of the corresponding Herakles Farnese type. ${ }^{119}$

\section{Conclusion}

Apart from sites where sanctuaries would be expected, such as in cities or the sites of identified settlements such as Aiane, Heraclea Lyncestis, Petres, and Eratyra, the other attested sanctuaries of Upper Macedonia are located in various places (Map 1): a) at the crests of hills or on mountaintops (sanctuaries of Zeus Hypsistos); b) at hubs, probably because of a cult's wide influence (sanctuaries of Apollo), and c) at passages, either because of a cult's dissemination (sanctuaries of Enodia), or its particular nature (e.g. a cult connected with crossroads, such as the sanctuaries of Hecate). Thus, sanctuary locations follow the general geographical distribution of cities and settlements with only minor deviations. According to the present excavation data, these sanctuaries do not display monumentality, which is a characteristic of at least the western part of Macedonia.

Archaeological Museum of Thessaloniki

Kalliopi G. CHATZINIKOLAOU

M. Andronikou, 6

GR - 54621 THESSALONIKI

E-mail:kchatrini@yahoo.gr

\section{List of figures}

Map 1. Upper Macedonia. Sanctuary sites: Extracts from the General Use Maps of the Hellenic Military Geographical Service (HMGS) on a scale of 1:1,000,000 were used to draw up the map in this text. The extracts were taken from the Gazettes of Thessaloniki 1979, Patras and Corfu 1976, on a scale of 1:1 with the approved and issued publication permit under Protocol Number X-1760, HMGS, 5th Management, ҮГЕПОА.

Fig. 1a. Sanctuary of Zeus at Petres in Florina, "Synoikia tis Krinis" (1) [modified from AdAm-Veleni (1998b), plan 5].

Fig. 1b. View of the sanctuary of fig. 1a (after: P. Adam-Velent, D. Kalliga, Z. Al SAayah,

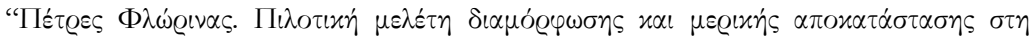

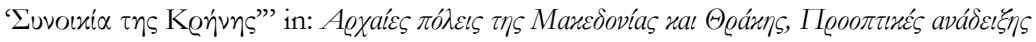

118 Rizakis, Touratsoglou (1985), p. 95-96 nr. 97, pl. 35 with previous bibliography; Iliadou (1998), p. 152-153 nr. 6. Cf. KARAMitrou-MeNTESSIDI (1993a), p. 78, 80-81 fig. 45 (simple mention); ChatzinikolaOU (2007), Catalogue, nr. 196.

119 O. Palagia, s.v. "Herakles", LIMC IV, (1988), p. 762-769. On the identification of the type, see also Rizakis, TOURATSOGLOU (1999), p. 953-954 n. 19. 


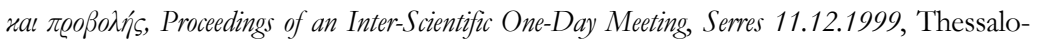
niki, 2008, p. 85-110, fig. 5).

Fig. 2-3. Votive stelae to Zeus Hypsistos from the hill of Hagios Eleutherios in Kozani [after: Rizakis, TOuratsoglou (1985), pl. 2 fig. 5, pl. 6 fig. 21].

Fig. 4-5. Votive stele to Zeus Hypsistos (fig. 4) and statuette of an eagle with a dedicatory inscription to the god (fig. 5), probably from the hill of Hagios Eleutherios in $\mathrm{Ko}$ zani or from Ano Komi [after: Rizakis, Touratsoglou (1985), pl. 4 fig. 10, pl. 7 fig. 17].

Fig. 6. Statuette of an eagle with a dedicatory inscription to Zeus Hypsistos from Aiane [after: Rizakis, Touratsoglou (1985), pl. 3 fig. 7].

Fig. 7. Part of an architectural member with a dedicatory inscription to Zeus Hypsistos from Ano Komi [after: Rizakis, Touratsoglou (1985), pl. 6 fig. 16].

Fig. 8. Part of a votive relief to Zeus Hypsistos from Aiane [Photograph: K. CHATZINIKOLAOU].

Fig. 9. Slab with dedicatory inscription to Dionysus from Ano Komi [after: RizAKIS, Touratsoglou (1985), pl. 4 fig. 11].

Fig. 10. Bronze figurine of Dionysus from Xirolimni [after: KARAMITROU-MENTESSIDI (2001b), fig. 2].

Fig. 11. View of the sanctuary at Xirolimni [after: Karamitrou-MENTESSIDI (2001b), fig. 1].

Fig. 12-16. Parts of statuettes, votive reliefs, and stelae from the sanctuary of Apollo at Xirolimni [after: KARAMITROU-MENTESSIDI (2001a), fig. 7, 13, KARAMitrouMENTESSidi (2001b), fig. 4 (fig. 12-13, 16), KARAMitrou-MENTESSidi (1999), fig. 91-92 (fig. 14-15)].

Fig. 17. Statuette of Apollo from Komanos in Eordaia [after: RizAKIS, TOURATSOGLOU (1985), pl. 37 fig. 100] .

Fig. 18. Votive relief to Apollo Lykios from Vergina (after: CHR. SAATSOGLOU-PALIADELI, "A

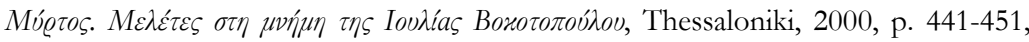
fig. 1).

Fig. 19. Votive relief to Apollo Pythios and Artemis Hegemone from Kalindoia (after:

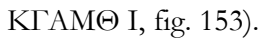

Fig. 20. Relief depicting Athena from Petres in Eordaia [after: ADAM-VELENI (1987), pl. 1].

Fig. 21. Statuette of Athena from Bukovo (F.Y.R.O.M.) [after: DüLL (1977), fig. 27].

Fig. 22a-b. Votive relief to Pluto from Aiane [after: Rizakis, Touratsoglou (1985), pl. 5 fig. 15].

Fig. 23. Hekataion from the sanctuary of Hecate in Orestis [after: CHRYSOSTOMOU (1998), pl. $24 \gamma]$.

Fig. 24. Votive relief to Enodia from Hagia Paraskevi (Elimeia), [after: CHRYsosTOMOU (1998), pl. $14 \alpha$ ].

Fig. 25-28. Votive offerings to Enodia from the sanctuary at Exochi [after: Rizakis, TOURATSOGLOU (1985), pl. 34 fig. 94, pl. 36-37 fig. 98-100a].

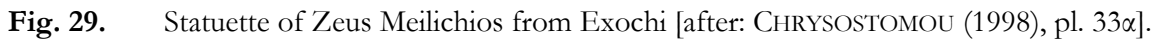

Fig. 30. Votive relief to Dea Syria, probably from Exochi [after: RIzAKIS, TOURATSOGLOU (1985), pl. 38 fig. 102].

Fig. 31. Votive stele to Herakles Kynagidas from Ryakio in Eordaia [after: RIZAKIS, Touratsoglou (1985), pl. 35 fig. 97]. 


\section{Abbreviations - Bibliography}

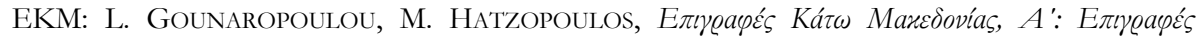
Beooías, Athens, 1998.

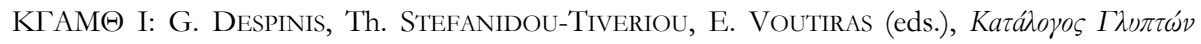

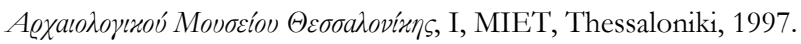

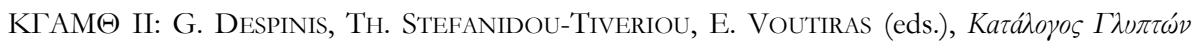

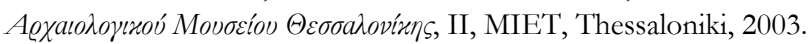

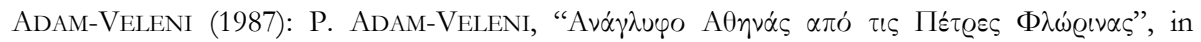

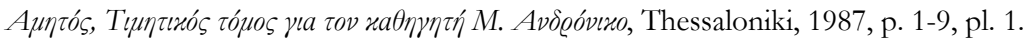

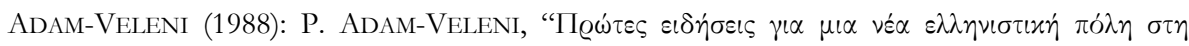

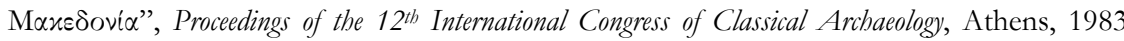
[1988], $\Delta^{\prime}$ ', p. 7-11, pl. 1-2.

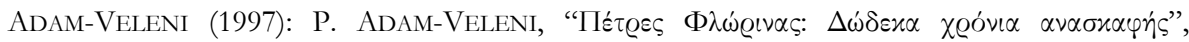
AEMTh 10A (1996) [1997], p. 1-22.

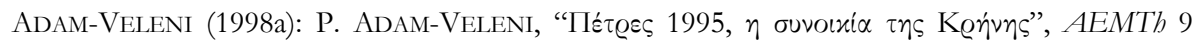
(1995) [1998], p. 15-23.

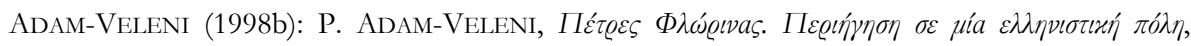
(Archaeological Guide), Thessaloniki, 1998.

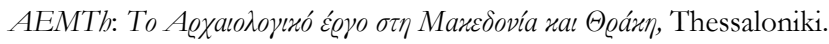

Baege (1913): W. BAege, De Macedonum sacris. Dissertationes philologicae Hallenses, XXII 1, (Hallis Saxonum), Halle, 1913.

Chapouthier (1935): F. Chapouthier, Les Dioscures an service d'une déesse. Étude d'iconographie religieuse, Paris, 1935 (BEFAR, 137).

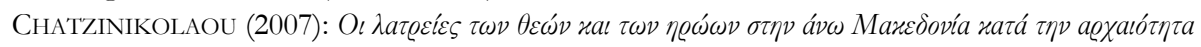

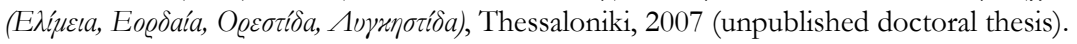

Chatzinikolaou (2008): K.G. Chatzinikolalou, "Zeus Hypsistos. Un dieu d'origine macédonienne ou bien orientale ? Remarques sur la redatation de trois reliefs votifs inscrits de la Haute Macédoine", in XVII International Congress of Classical Archaeology, Rome, 2008 (forthcoming).

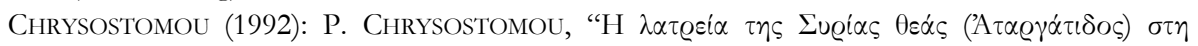

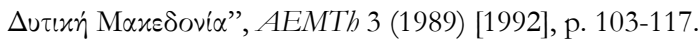

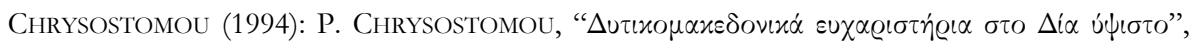
AEMTh 5 (1991) [1994], p. 97-110.

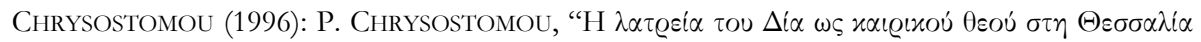

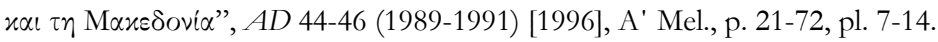

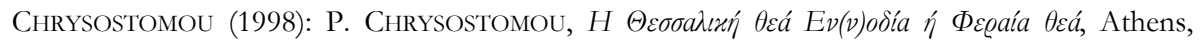
1998.

DÜLL (1977): S. DÜLL, Die Götterkulte Nordmakedoniens in römischer Zeit. Eine kultische und typologische Untersuchung anbang epigraphischer, numismatischer und arcbäologischer Denkmäler, München, 1977 (Münchener archäologische Studien, 7).

Gaebler (1906): H. Gaebler, Die antiken Münzen von Makedonia und Paionia, I, Berlin, 1906.

Gaebler (1935): H. GAebler, Die antiken Münzen von Makedonia und Paionia, II, Berlin 1935.

Hammond, Griffith (1979): N.G.L. Hammond, G.T. Griffith, A History of Macedonia, II, 550336 BC, Oxford, 1979.

HeAD (1911): B.V. HEAD, Historia Numorum. A manual of Greek Numismatics (assisted by G.F. HiLl, G. MACDONALD, W. Wroth), Oxford, 1911. 
Héraclée I (1961): P. MAČKIĆ, I. MikulČIĆ, Catalogue des objets antiques d'Héraclée, Bitola, 1961.

Iliadou (1998): P. Iliadou, Herakles in Makedonien, Hamburg, 1998 (Antiquitates, Archäologische Forschungsergebnisse, 16),

Kalpakovska, Gjorgjievska (2003): V. Kalpakovska, A. Gjorgjievska, Životot vo Heraclea Lyncestis preku epigrafskite spomenici (The Lifestyle in Heraclea Lyncestis via epigraphic monuments), Zavod za zaštita na spomenicite na kulturata, Musej i Galerija, Bitola, 2003.

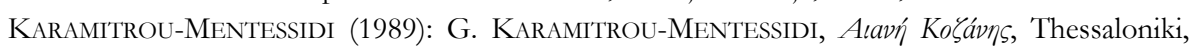
1989 (Archaeological Guide).

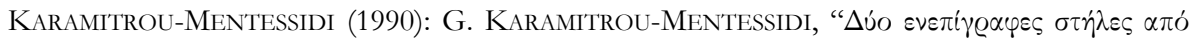

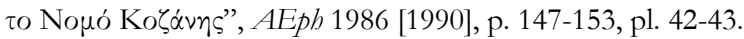

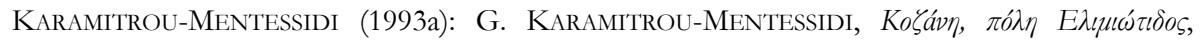
Thessaloniki, 1993 (Archaeological Guide).

Karamitrou-Mentessidi (1993b): G. Karamitrou-Mentessidi, "H $\alpha \varrho \chi \alpha i \alpha$ Aı $\alpha$ v'”, in Ancient Macedonia V, Papers read at the Fifth International Symposium held in Thessaloniki, October 10-15, 1989, Manolis Andronikos in memoriam, Thessaloniki 1993 (Institute for Balkan Studies, 240), p. 653-667.

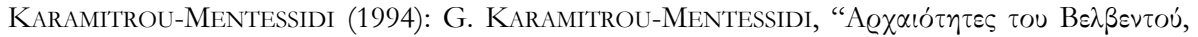

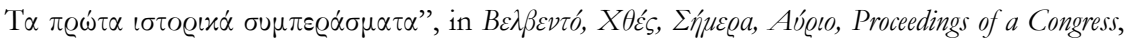
1993, Thessaloniki, 1994, p. 41-98.

Karamitrou-Mentessidi (1996): G. Karamitrou-Mentessidi, Aıavŕ, Athens, 1996, (Archaeological Guide).

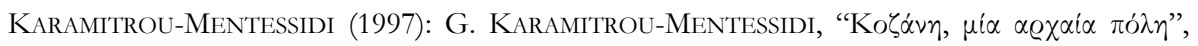

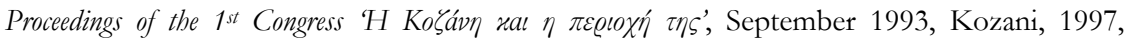
p. 203-231.

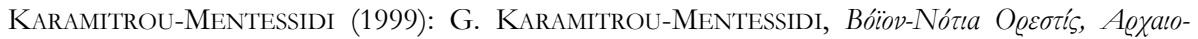

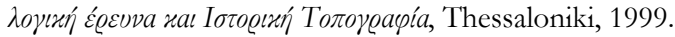

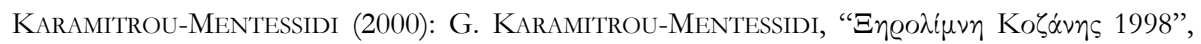
AEMTh 12 (1998) [2000], p. 465-480.

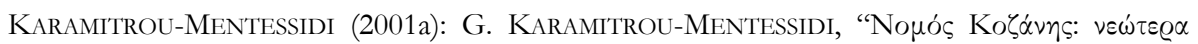

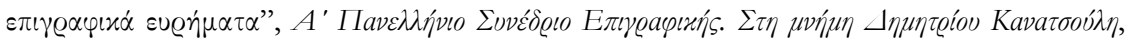
Thessaloniki 22-23 October 1999, Thessaloniki, 2001, p. 49-78.

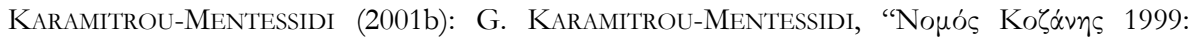

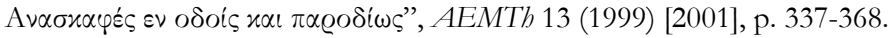

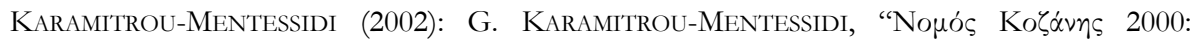

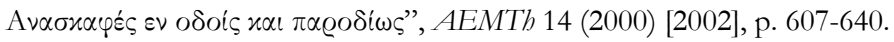

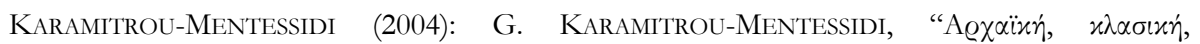

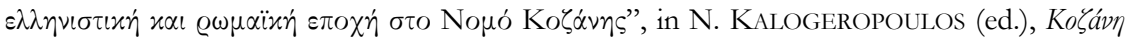

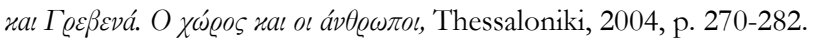

Liampi (1998): K. Liampi, "The coinage of King Derdas and the history of the Elimiote Dynasty", in A. Burnett, U. Wartenberg, R. Witschonke (eds.), Coins of Macedonia and Rome: Essays in honour of Charles Hersh, SPINK, London, 1998, p. 5-12, pl. 1-2.

Nigdelis, SOuRIS (1996) : P.M. NigDelis, G.A. SOURIS, "A

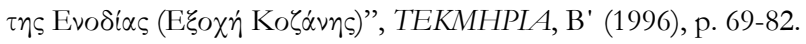

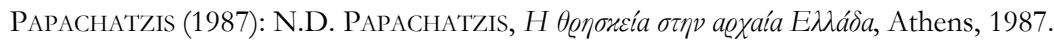

Papazoglou (1988): F. Papazoglou, Les villes de Macédoine à l'époque romaine, Paris, 1988 (BCH, suppl. 14).

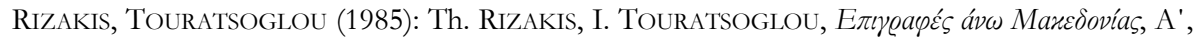
Athens, 1985. 


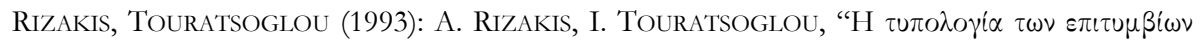

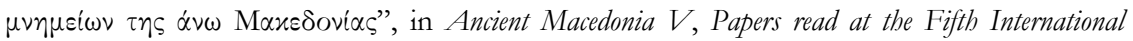
Symposium held in Thessaloniki, October 10-15, 1989, Manolis Andronikos in memoriam, Thessaloniki, 1993 (Institute for Balkan Studies, 240), 2, p. 1285-1300.

Rizakis, Touratsoglou (1999): A. Rizakis, I. Touratsoglou, " $\Lambda \alpha \tau \varrho \varepsilon i \varepsilon \varsigma \sigma \tau \eta \nu \alpha \dot{\alpha} \omega$ M $\alpha \varkappa \varepsilon \delta o v i \alpha$,

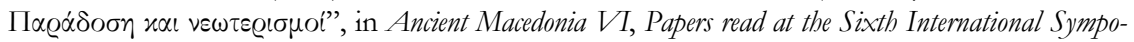
sium held in Thessaloniki, October 15-19, 1996, Julia Vokotopoulou in memoriam, Thessaloniki, 1999 (Institute for Balkan Studies, 272), 2, p. 949-965 .

SCHUMACHER (1996): L. SCHUMACHER, "Makedonien: Vom hellenistischen Königsreich zur römischen Provinz", in R. AlbeRT (ed.), Rom und Rhein - Macht und Münzen, Festschrift der Numismatischen Gesellschaft, Mainz/Wiesbaden, 1996, p. 35-59.

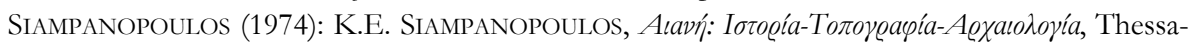
loniki, 1974.

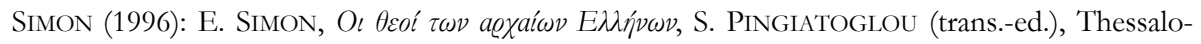
niki, 1996.

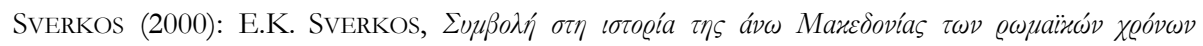

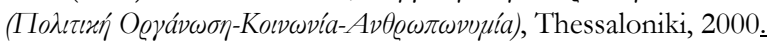

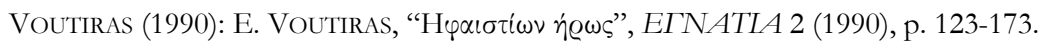

Voutiras (1998): E. Voutiras, “Athéna dans les cités de Macédoine”, Kernos 11 (1998), p. 111 129.

Voutiras (2006): E. VoutiRAs, "Le culte de Zeus en Macédoine avant la conquête romaine", in M. Guimier-Sorbets, M.B. Hatzopoulos, Y. Morizot (eds.), Rois, cités, nécropoles. Institutions, rites et monuments en Macédoine. Actes des colloques de Nanterre (décembre 2002) et d'Athènes (janvier 2004), Athènes, 2006 (Meletemata, 45), p. 333-345.

VuliĆ (1937): N. VuliĆ, Archäologische Karte von Jugoslavien: Blatt Prilep-Bitolj, Beograd, 1937.

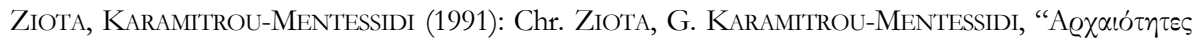

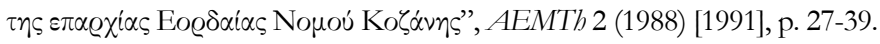

